\title{
A Review of Non-Invasive Haptic Feedback stimulation Techniques for Upper Extremity Prostheses
}

\author{
Mohammed Najeh Nemah ${ }^{1,2}$, Cheng Yee Low ${ }^{1, *}$, Omar Hammad Aldulaymi ${ }^{1}$, \\ Pauline Ong ${ }^{1}$, Al Emran Ismail ${ }^{1}$, Abdullah Ali Qasim ${ }^{1}$
}

${ }^{1}$ Faculty of Mechanical and Manufacturing Engineering, Universiti Tun Hussein Onn Malaysia, Parit Raja, Batu Pahat, Johor, 86400, MALAYSIA

${ }^{2}$ Engineering Technical College-Najaf, Al-Furat Al-Awsat Technical University, Najaf, 32001, IRAQ

*Corresponding Author

DOI: https://doi.org/10.30880/ijie.2019.11.01.030

Received 02 December 2018; Accepted 13 February 2019; Available online 30 April 2019

\begin{abstract}
:
A sense of touch is essential for amputees to reintegrate into their social and work life. The design of the next generation of the prostheses will have the ability to effectively convey the tactile information between the amputee and the artificial limbs. This work reviews non-invasive haptic feedback stimulation techniques to convey the tactile information from the prosthetic hand to the amputee's brain. Various types of actuators that been used to stimulate the patient's residual limb for different types of artificial prostheses in previous studies have been reviewed in terms of functionality, effectiveness, wearability and comfort. The non-invasive hybrid feedback stimulation system was found to be better in terms of the stimulus identification rate of the haptic prostheses' users. It can be conclude that integrating hybrid haptic feedback stimulation system with the upper limb prostheses leads to improving its acceptance among users.
\end{abstract}

Keywords: Prosthetic hand, Upper extremity prostheses, Upper limb amputation, Haptic feedback stimulation system, Hybrid feedback display, Feeling recovery, Non-invasive stimulation

\section{Introduction}

In spite of the fast progress in medical science over recent decades, patients of upper limb amputation have only little change in the daily life [1]. In fact, the amputees thought that most of the upper limb prostheses are still as a hook at the end of the arm [2]. According to the statistical study that has been made on 2477 amputees of upper limb mutilation [3], the basic requirement of the typical upper limb prostheses are: (i) enable the users to perform their daily life activities with less visual attention required, (ii) allow the patients to manipulate different sizes of objects as easy as possible, and (iii) design a prosthetic hand which has the highest similarity to the healthy human hand in overall appearance and functionality. However, the insufficiency to deliver exteroceptive [4] and proprioceptive [5] information makes the upper limb prostheses very difficult to control. Nowadays, many research efforts seek to overcome the challenges of the lack of sensation during using the prostheses and enable the amputees to discover their environment through their own prosthetic hands.

Some efforts have been made towards examining the ability to use the visual feedback information in performing both simple and complex tasks. To achieve this investigation, a single-eye display augmented reality (AR) feedback was designed and tested with an able-body volunteer to pick and lift objects in simple and complex duties [6, 7]. The study concluded that the AR feedback sensor has the ability to provide information of grasping force to the amputees in very 
helpful ways. In addition, the virtual feedback is an effective technique to compensate the lack of sensation, while using the prosthetic robotic hand.

On the other hand, the invasive and non-invasive techniques were used for the same purposes. The invasive technique depends on the surgical intervention to access the nervous system of the amputees, and pass the information directly from the tactile sensors to the user's brain. An implanted cuff electrodes external device has been used to generate square, biphasic, and charge balanced pulses that are delivered to the nerves to restore the sensation at the fingertips of the upper limb prostheses [8,9]. Most opinions encourage the use of non-surgical intervention (non-invasive technique), in which the lack of sensation at the missing part can be compensated by stimulating other parts of the body using an external stimulus to excite the patients' skin [10].

The non-invasive haptic feedback stimulation system usually is coupled with the myoelectric prosthetic hand for improving its controller performance and recovering the sensation. The myoelectric prosthetic drives by the bio-signal, such as the electric muscle activity of the residual limb. A bio-signal is any signal in living beings that can be continually measured and monitored. The muscle activity is usually recorded with surface electromyography (EMG) by electrodes positioned on the residual limb [11]. Fig. 1 explains the signal flow's block diagram of myoelectric prostheses. The biosignals measured by EMG sensors record and amplify the muscle activity. After analog/digital conversion, the control system processes and interprets the EMG data. The control system's output signal is used to drive the robotic hand by controlling its driving motors. In general, the Lagrange's equation and model expansion method can be utilized to develop the dynamic equations of the prosthetic hand during the design and development stage [12-17]. Finally, the position, velocity, acceleration, and the grasping strength of the prosthetic hand can be measured by the sensory system and used as feedback to the controller to enhance its performance.

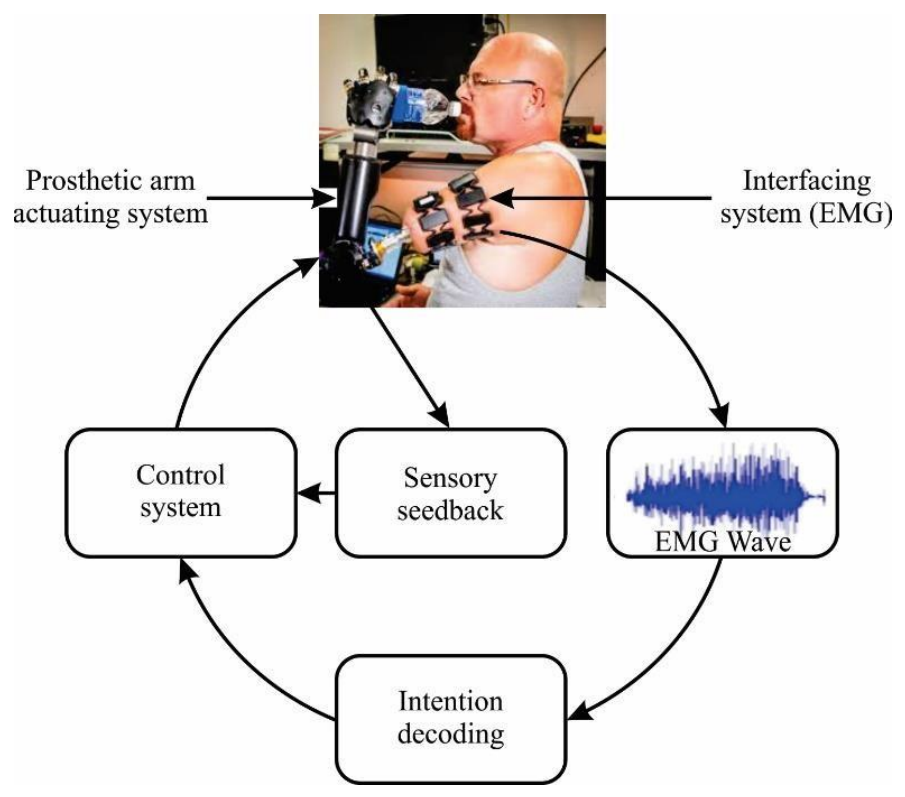

Fig. 1 - Signal flow's block diagram of myoelectric prostheses.

On the other side, the importance of providing feeling from the tactile prosthetic hand to the patient is not only limited to transferring the feeling of the handgrip, but it also helps the user to control the applied contact force to prevent sliding object. In addition, the main important function of the haptic system is to enable the user to detect surface type, roughness, temperature, humidity, and rigidity, depending on the sensing types that used in the tactile system. Usually, the tactile sensors mount on one or more fingertip of the prosthetic hand or sometimes cover entire prosthetic hand. The main function of the tactile sensory system is to measure the environmental parameters and provide it to the microcontroller as analog signals, in order to process the data. The decision orders that output from the microcontroller using as a manipulating signal to drive the haptic feedback actuators, in order to excite the nervous system of the amputee's residual limb. Such excitation transfers the feeling to the patient's brain and enables him to recognize his environment through his prosthetic hand. For example, the main steps of the force-pressure detection in a tactile feedback stimulation system are presented in Fig. 2. a. The grasp force is measured and transferred to a pressure stimulation on the forearm skin to excite the patient's brain. The haptic feedback stimulation system can be further classified into six displays, depending on how to stimulate the patient's skin and provide the information of the tactile sensory system to the amputee's brain. The six haptic feedback displays are the pressure feedback display, the vibration feedback display, the skin stretch feedback display, the squeeze feedback display, the electro feedback display, and the thermal feedback display, as shown in Fig. 2. b. The combination of two or more types of haptic feedback displays leads to create an unusual multi-mode feedback technique, such a system is called the hybrid feedback display. 
a
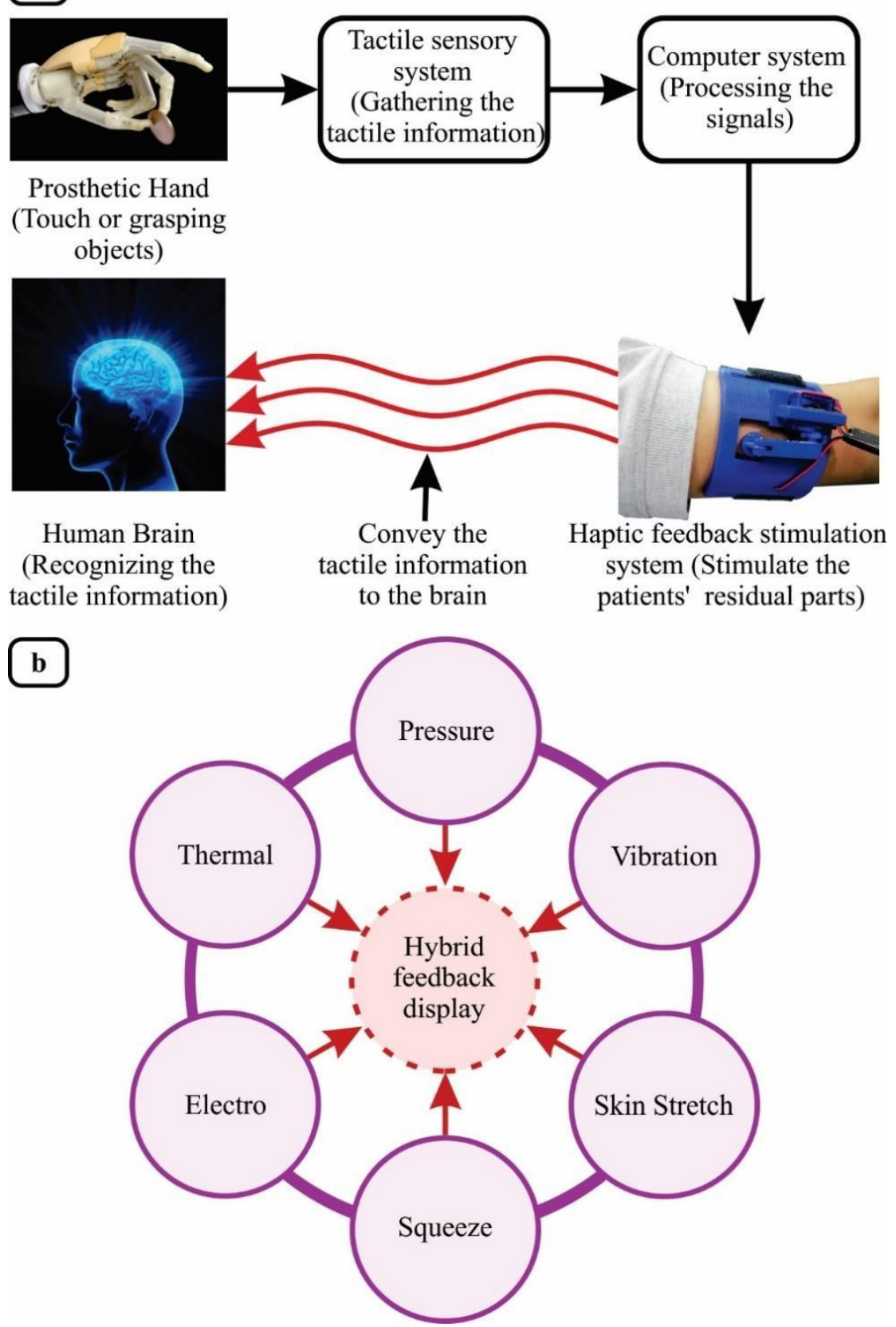

Fig. 2 - Haptic feedback stimulation techniques for upper extremity prostheses: a) system overview; b) The main types.

In general, the haptic feedback stimulation system consists of three main parts: the tactile sensory system, the computer system, and the feedback stimulation system. The tactile sensory system is responsible for gathering the tactile information on the prosthetic hand and transferring it to measurable signals. The computer system is in charge of processing the tactile signals and manipulating the excitation signals to control the feedback actuators. Lastly, the feedback stimulation system consists of mechanical or electrical actuators which have the ability to excite the amputees' residual parts to stimulate the skin and convey the tactile information to the users' brain in a quiet manner.

Based on previous studies, the tactile sensory system can be classified into five classes according to its function. The five classes are: pressure detection sensory system [18-20], slippage detection sensory system [21, 22], surface texture detection sensory system [23, 24], material detection sensory system [25, 26], and temperature detection sensory system $[27,28]$. The challenges on how to combine two or more types of tactile sensors to form a hybrid sensory systems which has the ability to measure multi types of tactile information simultaneously have been addressed in some studies [29, 30]. 
The general idea behind most of the tactile sensors that using with the prostheses is utilizing material, resistor, capacitor, conductive rubber, or other materials that have the ability to change the current pass through it and then change its output voltage when the sensory affected of an external disturbance like force, temperature, or vibration. For instance, the tactile glove equipped with multi Quantum Tunnelling Composite (QTC) pressure sensors has been developed by NASA/DARPA in order to modify autonomous grasping skills of a dexterous humanoid robot [31]. On the other hand, the force sensitive resistor sensor (FSR) was installed on the fingertip of a 3D printed prosthetic hand to detect the grasping contact force and enable the user to generate a suitable grasping force to carry the object without slipping [32]. The surface texture detection is available to the patient who uses the haptic artificial hand by attaching a vibration sensor on the fingertip of the prosthetic hand. When the finger slides over the surfaces, the vibration sensor provides wide variation of amplitude and frequency signals, depending on the hardness of the surfaces. These signals will be processed to generate a high wide range of feedback stimulation to the user and enable him to recognize the surface texture [33, 34].

The main objective of this study is to shed some light on the main techniques and the classification of the noninvasive haptic feedback stimulation system, which has been designed to help the patients who suffer from loss of their upper limb to recover the sensation through prosthetic hand. Furthermore, this literature aims to highlight the main types of actuators that commonly used to stimulate the patients' residual parts and the most common locations of installing these actuators. In addition, this paper presents a statistical analysis to the types of the prosthetic hand that been used in the experimental work in this field, the types and the number of the engaged volunteers, and the challenges that were faced in previous studies. When conducting a systematic search of the literature, the wearability, effectivity, comfort, and functionality criterions were placed on as the main standers to read, classify, and summarize the previous studies, as shown in Fig. 3.

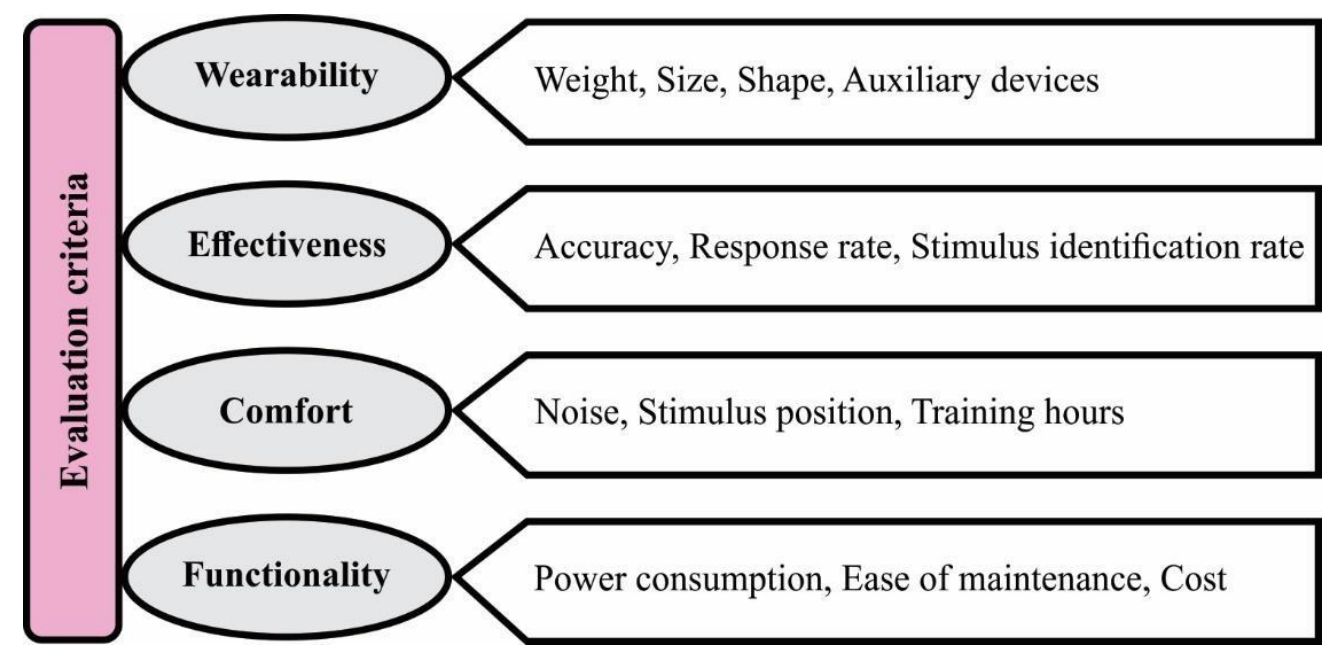

Fig. 3 - Evaluation criteria for literature review.

The rest of paper is organized as follows: the main non-invasive feedback stimulation techniques that usually used with the prosthetic hand are listed Section 2. Section 3 lists the studies that combine between two or more types of noninvasive feedback stimulation, called as hybrid feedback stimulation system. Discussion and statistical analysis of previous research and its main techniques are presented in Section 4. Finally, some conclusions and future work regarding this work are addressed in Sections 5.

\section{Non-Invasive Feedback Stimulation Techniques}

As presented in previous section, the essential purpose of the tactile sensory system is to measure and record the environment parameters and transfer it as directly proportional electrical signals. How to regenerate these signals and recover the sensation to the surrounding effecting parameters, how to deliver electrical signals as a tactile feeling to the patients' of upper limb amputation, and what are the main techniques that usually using for this purpose, are the main questions that will be presented in this section. In general, the non-invasive haptic feedback stimulation system is a wearable device designed to convey the tactile sensory information or the measurable sensory data to the kinesthetic or haptic sensation by activating the mechanoreceptors in the human skin [35]. In other words, the non-invasive feedback stimulation system is a mechanical, vibrational, or electro device, which has the ability to stimulate the patient's residual parts of the body.

\subsection{Pressure Feedback Display}


The pressure feedback display usually deals with conveying the tactile information to the user's brain by mean of pressing or vertically deforming the skin of the residual part [10]. Table 1 summarizes the works on the pressure feedback display.

A pressure wearable device was designed and installed on the forearm of fully able-body volunteers, to enhance the performance of the myoelectric prosthetic hand and recover the sensation of touch to its user [10]. The $15 \mathrm{~mm}$ plastic levers with $12 \mathrm{~mm}$ circular diameter plastic buttons powered by five digital servomotors (Graupner DS281, Germany) were used to apply pressure on the patient's skin, which was proportional to the amount of the measured contact pressure, as shown in Fig. 4. The same technique has been used in another study [36] to discernment the preferable location and the pressure level of the pressure feedback display, in order to deliver the grasping contact pressure to the user of the upper limb prostheses with high performance and an approval rating of recognition accuracy.

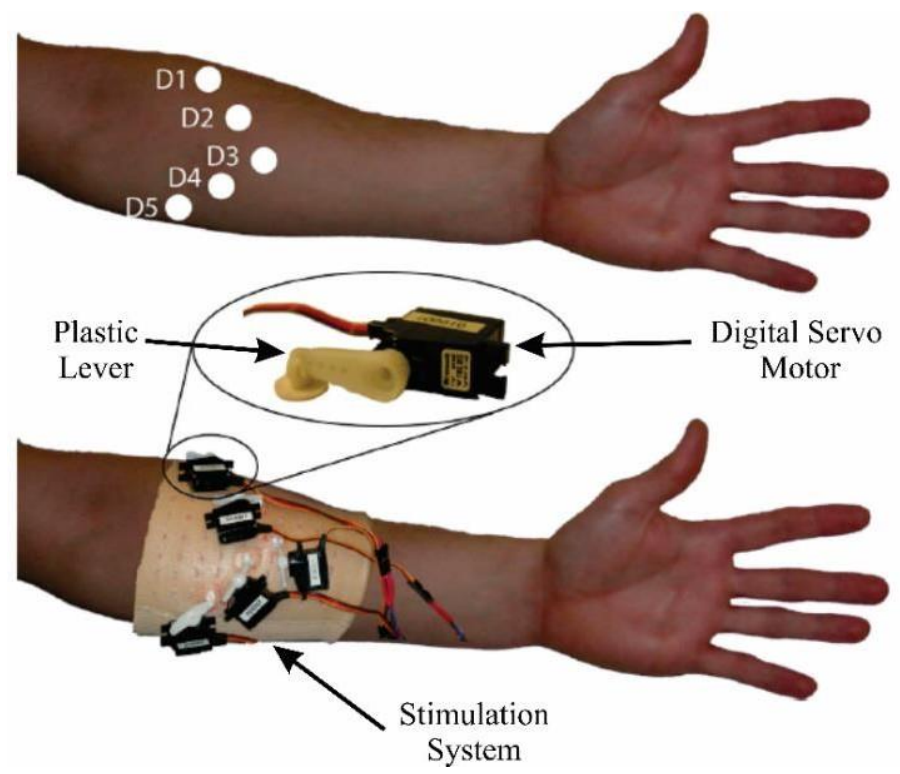

Fig. 4 - The distribution of the pressure stimulation system on the volunteer's forearm [10].

Five of the silicone-based balloon actuators (Marsh Bellofram T3210 type) were fixed on the fingertip of the two subjects that engaged in the study [37]. Five pressure actuators were used to excite the skin of the volunteers' fingertips by applying air pressure to deform the skin, which was related to the sensing signal provided from the sensor system. The generated pressure due to the connection force between the object and the prosthetic's fingers can be measured and directly translated to a pressure feedback stimulation by displacement of the patient's skin. The results found that subjects were able to discriminate the contact pressure in one finger and in three fingers at the same time with $99.3 \%$ and $90.2 \%$ identification accuracy, respectively.

On the other hand, the pressure feedback display was used to estimate the shape of the grasping objects by utilizing a multi-degree of freedom prosthetic hand [38, 39]. Subsequently, the estimated signals were transmitted by mean of Bilateral control to a single 3D printed pressing interfacing device to excite the thumb finger of the patient's foot. The authors found that the suggested haptic system is easier to operate than the classical systems without any training period. However, they recommended to follow a programmable training to improve using the haptic prosthetic hand in daily life.

Table 1 - Summary of the articles that dealt with the pressure feedback display.

\begin{tabular}{|c|c|c|c|c|c|c|}
\hline Ref. & $\begin{array}{c}\text { Location } \\
\text { of the } \\
\text { feedback } \\
\text { display }\end{array}$ & $\begin{array}{c}\text { Type of } \\
\text { the } \\
\text { artificial } \\
\text { hand }\end{array}$ & $\begin{array}{c}\text { Type of the } \\
\text { sensory } \\
\text { system } \\
\text { (Details) }\end{array}$ & $\begin{array}{c}\text { No of } \\
\text { healthy } \\
\text { volunteers / } \\
\text { No of } \\
\text { amputees } \\
\text { volunteers }\end{array}$ & $\begin{array}{c}\text { The details of } \\
\text { the using } \\
\text { stimulator }\end{array}$ & Finding and conclusion \\
\hline$[10]$ & Forearm & $\begin{array}{c}\text { Virtual } \\
\text { hand }\end{array}$ & $\begin{array}{c}\text { Virtual tactile } \\
\text { sensory } \\
\text { system }\end{array}$ & $2 / 0$ & $\begin{array}{c}\text { Five digital } \\
\text { servomotors } \\
\text { equipped with } 15 \\
\text { mm plastic } \\
\text { levers with } 12 \\
\text { mm circular }\end{array}$ & $\begin{array}{c}\text { The simple design of the } \\
\text { pressure display is } \\
\text { effective to improve the } \\
\text { performance of the } \\
\text { myoelectric prosthetic }\end{array}$ \\
\hline
\end{tabular}




\begin{tabular}{|c|c|c|c|c|c|c|}
\hline & & & & & $\begin{array}{l}\text { diameter plastic } \\
\text { buttons }\end{array}$ & $\begin{array}{l}\text { hand and recover the } \\
\text { sensation to it user. }\end{array}$ \\
\hline [36] & Forearm & $\begin{array}{l}\text { Virtual } \\
\text { hand }\end{array}$ & $\begin{array}{c}\text { Virtual tactile } \\
\text { sensory } \\
\text { system }\end{array}$ & $5 / 5$ & $\begin{array}{l}\text { Single digital } \\
\text { servomotor } \\
\text { equipped with } 15 \\
\text { mm plastic lever } \\
\text { with } 12 \mathrm{~mm} \\
\text { circular diameter } \\
\text { plastic button }\end{array}$ & $\begin{array}{c}\text { The location discernment } \\
\text { accuracy for healthy and } \\
\text { amputees volunteers are } \\
75.2 \% \text { and } 89.6 \% \\
\text { respectively. } \\
\text { The recognition of the } \\
\text { pressure in the two groups } \\
\text { are } 91.7 \% \text { and } 98.1 \% \\
\text { respectively. } \\
\text { Graspping force detection } \\
\text { accuracy are } 58.7 \% \text { and } \\
68.0 \% \text { respectively. }\end{array}$ \\
\hline [37] & Fingertip & $\begin{array}{l}\text { The study } \\
\text { didn't } \\
\text { include an } \\
\text { artificial } \\
\text { hand }\end{array}$ & $\begin{array}{c}\text { Pressure } \\
\text { sensor } \\
\text { (piezoresistive } \\
\text { sensors } \\
\text { Tekscan } \\
\text { FlexiForce of } \\
0 \text { to } 110 \mathrm{~N} \\
\text { operational } \\
\text { range and } 10 \\
\mathrm{~mm} \text { diameter) }\end{array}$ & $5 / 0$ & $\begin{array}{l}\text { Five of balloon } \\
\quad \text { actuators } \\
\text { connecting to a } \\
\text { single pressure } \\
\text { chamber }\end{array}$ & $\begin{array}{l}\text { The volunteers were able } \\
\text { to identify the correct } \\
\text { finger and detect three } \\
\text { simultaneous finger } \\
\text { stimuli with } 99.3 \% \text { and } \\
90.2 \% \text { accuracy, } \\
\text { respectively, }\end{array}$ \\
\hline $\begin{array}{l}{[38,} \\
39]\end{array}$ & Foot & $\begin{array}{l}\text { Multi } \\
\text { degrees of } \\
\text { freedom } \\
\text { developed } \\
\text { prosthetic } \\
\text { hand }\end{array}$ & $\begin{array}{l}\text { Reaction } \\
\text { Force } \\
\text { Observer was } \\
\text { utilized } \\
\text { to guess the } \\
\text { force applied } \\
\text { on motors }\end{array}$ & $0 / 1$ & $\begin{array}{l}\text { A single 3D } \\
\text { printed pressing } \\
\text { interfaceing } \\
\text { device to exite } \\
\text { the thumb finger } \\
\text { of the patient's } \\
\text { foot }\end{array}$ & $\begin{array}{l}\text { The suggested haptic } \\
\text { system is easier to operate } \\
\text { than the classical } \\
\text { systems without any } \\
\text { training period. }\end{array}$ \\
\hline [40] & Fingertip & $\begin{array}{l}\text { The study } \\
\text { didn't } \\
\text { include an } \\
\text { artificial } \\
\text { hand }\end{array}$ & $\begin{array}{l}\text { The study } \\
\text { didn't include } \\
\text { any sensor }\end{array}$ & $0 / 2$ & $\begin{array}{c}\text { A haptic } \\
\text { wearable device } \\
\text { with } 9 \mathrm{~N} \\
\text { maximum } \\
\text { pressing force }\end{array}$ & $\begin{array}{l}\text { The grip force control is } \\
\text { essentially improved by } \\
\text { using the haptic } \\
\text { stimulation system }\end{array}$ \\
\hline $\begin{array}{l}{[41,} \\
42]\end{array}$ & Fingertip & $\begin{array}{l}\text { The study } \\
\text { didn't } \\
\text { include an } \\
\text { artificial } \\
\text { hand }\end{array}$ & $\begin{array}{c}\text { A } \\
\text { piezoresistive } \\
\text { sensor and a } \\
\text { precise CCD } \\
\text { laser sensor } \\
\text { for measuring } \\
\text { the tactile } \\
\text { force and the } \\
\text { position, } \\
\text { respectively }\end{array}$ & $0 / 0$ & $\begin{array}{l}\text { portable haptic } \\
\text { glove with one } \\
\text { actuator for each } \\
\text { finger (Max } \\
\text { force } 10 \mathrm{~N} \\
\text { Displacement } \\
10-12 \mathrm{~mm} \text { ) }\end{array}$ & $\begin{array}{l}\text { The device produces a } \\
\text { force of } 7.5 \mathrm{~N} \text { for a } \\
\text { reasonable current of } 0.5 \\
\text { A. It is expected to reach } \\
12 \mathrm{~N} \text { if the saturation in } \\
\text { the } \\
\text { coil core is avoided }\end{array}$ \\
\hline
\end{tabular}

\subsection{Vibration Feedback Display}

The vibration feedback display is the method of restoring the missing sensations of individual fingers to the patient's brain by utilizing diverse kinds of vibrational simulators, like linear electromagnetic actuators, rotary electromagnetic actuators and non-electromagnetic actuators [43]. For example, attaching wearable armbands equipped with four vibrating motors on the user's upper arm and forearm to convey information about collisions that occur on a 6-degreesof-freedom robotic arm has been studied [44]. A brief summary of works on vibration feedback display is presented in Table 2.

Fifteen participants (fourteen males and one female) are engaged in previous work [45], in order to evaluate the performance of two different types of vibration stimulation display: the linear resonant actuators (LRAs) and the eccentric rotating masses (ERMs). The feedback system consists of nine stimulators from each actuator type, i.e., the LRA and ERM. From the obtained results, the authors concluded that LRAs are more useful than ERMs when dealing with binary 
information, and less power consumption, while the ERMs can be utilized for handover the complex signals. On the other hand, the vibration feedback stimulation display was used to train the patient on how to use his myoelectric prosthetic hand with high performance [46]. The haptic system was designed to increase the ability of the user to perform multitask with his prostheses within an acceptable accuracy. Five haptic rotative actuators were used to convey the contact pressure information of 14 (CZN-CP6) resistive pressure sensors. The experiments confirmed that the feedback mechanisms assisted the two patients of right hand missing to upgrade a cerebral automatism for usual movements and to respond in real time to multi external effects.

The tactile feedback system consists of an FSR pressure sensor, 3D printer prosthetic hand, and shaft-less, small size, coin shaped vibration motors of $10 \mathrm{~mm}$ diameter are designed and developed in [32], as shown in Fig. 5. A. The main objective of the study is to implement the amputee a much response during holding and releasing objects. Stimulation sequences are used to make the amputee interacts with the environment comfortably. The sequences are high vibration during $0.5 \mathrm{sec}$ at the instant of grasping and releasing the objects and periodically excitation in between to provide the user with sense that he is holding the object continuously. The behavior of the stimulation response when holding the empty bottle was shown in Fig. 5. B. The results proved the effectiveness of the vibrotactile system to increase the ability of the prosthetic hand used to manipulate the objects of different sizes.

(A)

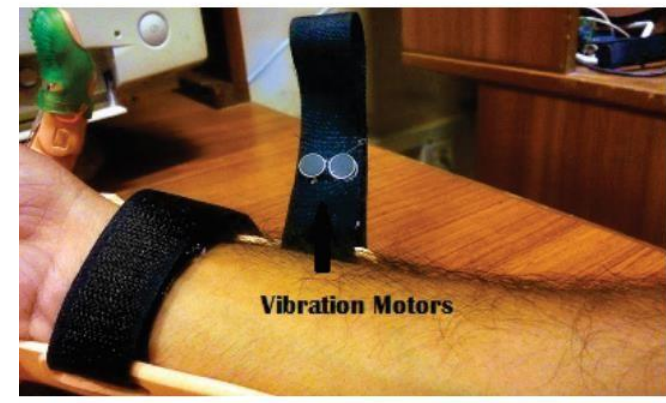

(B)

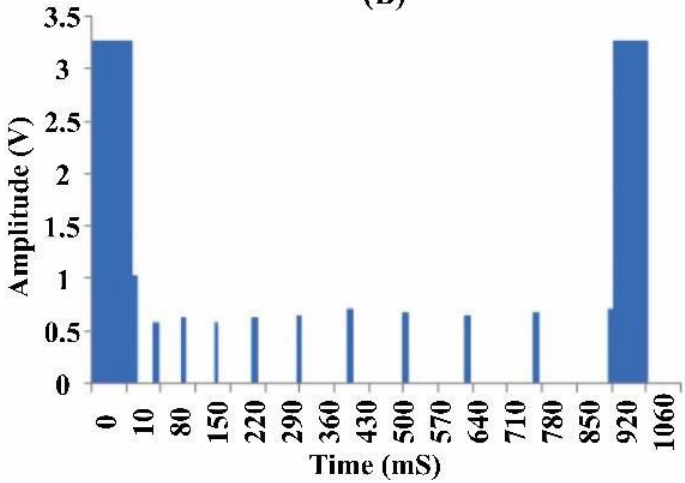

Fig. 5- A) Vibration motors on the forearm. B) The stimulation response during holding the empty bottle.

It is worth mentioning that the location of installing the vibration feedback stimulators is completely depended on the amputation levels of the patients. Indeed, it depends completely on the mutilation level of the upper limb amputees and the nerves state of their residual parts. Therefore, previous research investigated several locations of the haptic vibrotactile system. The $\mathrm{C} 2$ vibrotactile stimulator (Engineering Acoustics, Inc., Casselberry, FL) has been installed on the upper arm of 23 healthy volunteers, in order to help the users of the upper limb prostheses to detect the slippage and prevent slipping object before dropping it in high response and acceptable accuracy [47]. Vibrotactile stimulation is capable to provide amputees with the extraordinary sensing of embodiment in their prosthetic when installing at the forearm of the patients [48]. On the other hand, five spot vibration feedback actuators are distributed over the fingers of healthy hand, with one motor for each finger, in order to detect the level of the contact pressure that was created by a virtual sensory system [49]. The $\mathrm{C} 2$ tactors are very effective to convey the tactile information to the subjects' brain when using as a haptic wearable belt fixed around the amputees' waist [50]. Finally, the effect of training to increase the recognition to the tactile feedback information of different surfaces texture when the vibrotactile stimulator installed on the neck was investigated [51]. It is found that the ability of the volunteers to correctly detect the texture of different surfaces was increased by $16 \%$ after four weeks of training.

Table 2 - Summary of the articles that dealt with the vibration feedback display.

\begin{tabular}{|c|c|c|c|c|c|c|}
\hline Ref. & $\begin{array}{c}\text { Location } \\
\text { of the } \\
\text { feedback } \\
\text { display }\end{array}$ & $\begin{array}{c}\text { Type of the } \\
\text { artificial } \\
\text { hand }\end{array}$ & $\begin{array}{c}\text { Type of the } \\
\text { sensory } \\
\text { system }\end{array}$ & $\begin{array}{c}\text { No of healthy } \\
\text { volunteers / } \\
\text { No of } \\
\text { amputees } \\
\text { volunteers }\end{array}$ & $\begin{array}{c}\text { The details of } \\
\text { the using } \\
\text { stimulator }\end{array}$ & $\begin{array}{c}\text { Finding and } \\
\text { conclusion }\end{array}$ \\
\hline$[43]$ & $\begin{array}{c}\text { Upper arm } \\
\text { and } \\
\text { Forearm }\end{array}$ & Virtual hand & $\begin{array}{c}\text { Virtual tactile } \\
\text { sensory } \\
\text { system }\end{array}$ & $30 / 0$ & $\begin{array}{c}\text { Three } 10 \mathrm{~mm} \\
\text { circular vibration } \\
\text { motors (Precision } \\
\text { Microdrives Ltd, } \\
\text { UK) }\end{array}$ & $\begin{array}{c}\text { The volunteers were } \\
\text { able to detect the } \\
\text { touch and the gripping } \\
\text { force with } 94 \% \text { and } \\
85 \% \text { average accuracy, } \\
\text { respectively }\end{array}$ \\
\hline
\end{tabular}




\begin{tabular}{|c|c|c|c|c|c|c|}
\hline [44] & $\begin{array}{l}\text { Upper arm } \\
\text { and } \\
\text { Forearm }\end{array}$ & $\begin{array}{l}\text { Robotic } \\
\text { teleoperation } \\
\text { hand }\end{array}$ & $\begin{array}{l}\text { A six-axis } \\
\text { force-torque } \\
\text { sensor with a } \\
\text { diameter of } \\
75.4 \mathrm{~mm} \text { and } \\
\text { a weight } \\
\text { of } 0.255 \mathrm{~kg}\end{array}$ & $12 / 0$ & $\begin{array}{c}\text { Four Precision } \\
\text { Microdrives } 307- \\
100 \text { Pico } \\
\text { vibration } 9 \mathrm{~mm} \\
\text { vibration motors }\end{array}$ & $\begin{array}{c}\text { The effectiveness of } \\
\text { the robotic hand with } \\
\text { the vibration feedback } \\
\text { stimulation increased } \\
\text { by } 111 \% \text {, as } \\
\text { compared with robotic } \\
\text { hand without haptic } \\
\text { system }\end{array}$ \\
\hline [45] & Upper arm & Virtual hand & $\begin{array}{l}\text { Virtual tactile } \\
\text { sensory } \\
\text { system }\end{array}$ & $15 / 0$ & $\begin{array}{l}\text { Nine of each } \\
\text { LRA and ERM }\end{array}$ & $\begin{array}{l}\text { The LRAs are more } \\
\text { useful than ERMs } \\
\text { when dealing with } \\
\text { binary information and } \\
\text { use less power } \\
\text { consumption }\end{array}$ \\
\hline [46] & Forearm & $\begin{array}{l}\text { Prosthetic } \\
\text { hand }\end{array}$ & $\begin{array}{l}14(\mathrm{CZN}- \\
\mathrm{CP} 6) \text { resistive } \\
\text { pressure } \\
\text { sensors }\end{array}$ & $1 / 2$ & $\begin{array}{l}\text { Five small haptic } \\
\text { rotative actuators }\end{array}$ & $\begin{array}{l}\text { The experiments } \\
\text { confirmed that the } \\
\text { feedback mechanisms } \\
\text { assisted the two } \\
\text { patients of right hand } \\
\text { missing to upgrade a } \\
\text { cerebral automatism } \\
\text { for usual movements } \\
\text { and to respond in real } \\
\text { time to multi external } \\
\text { affects }\end{array}$ \\
\hline [32] & Forearm & $\begin{array}{l}\text { 3D printer } \\
\text { prosthetic } \\
\text { hand }\end{array}$ & $\begin{array}{l}\text { FSR pressure } \\
\text { sensor with } \\
0.5 \text {-inch } \\
\text { diameter }\end{array}$ & $0 / 6$ & $\begin{array}{l}\text { Shaft-less, small } \\
\text { size, coin shaped } \\
\text { vibration motors } \\
\text { of } 10 \mathrm{~mm} \\
\text { diameter }\end{array}$ & $\begin{array}{l}\text { The results proved the } \\
\text { effectiveness of the } \\
\text { vibrotactile system to } \\
\text { increase the ability of } \\
\text { the prosthetic hand } \\
\text { used to manipulate the } \\
\text { objects of different } \\
\text { sizes }\end{array}$ \\
\hline [47] & Upper arm & Virtual hand & $\begin{array}{l}\text { Phantom's } \\
\text { stylus to } \\
\text { record the } \\
\text { position and } \\
\text { the force of } \\
\text { the virtual } \\
\text { hand }\end{array}$ & $23 / 0$ & $\begin{array}{l}\text { Vibrating C2 } \\
\text { tactor } \\
\text { (Engineering } \\
\text { Acoustics, Inc., } \\
\text { Casselberry, } \\
\text { FL) }\end{array}$ & $\begin{array}{l}\text { The authors concluded } \\
\text { that the proposed } \\
\text { haptic system is able } \\
\text { to help the user to } \\
\text { detect the slippage and } \\
\text { prevent slipping object } \\
\text { before dropping it }\end{array}$ \\
\hline [48] & Forearm & Rubber hand & $\begin{array}{l}\text { Skin } \\
\text { conductance } \\
\text { response } \\
\text { (SCR) }\end{array}$ & $0 / 9$ & $\begin{array}{c}\text { Two distinct } \\
\text { miniature } \\
\text { vibrators (310- } \\
101 \text { series, } \\
\text { Precision } \\
\text { Microdrives UK) }\end{array}$ & $\begin{array}{l}\text { Vibrotactile } \\
\text { stimulation is capable } \\
\text { to provide amputees } \\
\text { with the massive } \\
\text { sensing of } \\
\text { embodiment. }\end{array}$ \\
\hline [49] & Fingertip & Virtual hand & $\begin{array}{l}\text { Virtual tactile } \\
\text { sensory } \\
\text { system }\end{array}$ & $5 / 0$ & $\begin{array}{l}\text { Five ERM spot } \\
\text { vibrators (iNeed } \\
\text { Inc., HK), one } \\
\text { actuator for each } \\
\text { finger of the } \\
\text { healthy hand. }\end{array}$ & $\begin{array}{c}\text { The subjects are } \\
\text { capable to detect the } \\
\text { level of the contact } \\
\text { pressure by mean of } \\
\text { the vibration feedback } \\
\text { display }\end{array}$ \\
\hline [50] & Waist & $\begin{array}{l}\text { The study } \\
\text { didn't } \\
\text { include an } \\
\text { artificial } \\
\text { hand }\end{array}$ & $\begin{array}{l}\text { Virtual tactile } \\
\text { sensory } \\
\text { system }\end{array}$ & $14 / 0$ & $\begin{array}{l}\text { Belt with four } \mathrm{C} 2 \\
\text { tactors }\end{array}$ & $\begin{array}{l}\text { The } \mathrm{C} 2 \text { tactors are } \\
\text { very effective to } \\
\text { convey the tactile } \\
\text { information to the } \\
\text { subjects' brain }\end{array}$ \\
\hline
\end{tabular}




\begin{tabular}{|c|c|c|c|c|c|c|}
\hline$[51]$ & Neck & $\begin{array}{l}\text { Industrial } \\
\text { Universal } \\
\text { Robot } \\
\text { manipulator, } \\
\text { UR5 }\end{array}$ & $\begin{array}{l}\text { CoRo, at } \\
\text { École de } \\
\text { technologie } \\
\text { supérieure } \\
\text { (ÉTS) multi- } \\
\text { modal } \\
\text { capacitive } \\
\text { tactile sensor }\end{array}$ & $21 / 0$ & $\begin{array}{l}\text { Haptuator Mark } \\
\text { II cylindrical } \\
\text { vibration motor }\end{array}$ & $\begin{array}{l}\text { The ability of the } \\
\text { volunteers to correctly } \\
\text { detect the texture of } \\
\text { the different surfaces } \\
\text { was increased by } 16 \% \\
\text { after four weeks of } \\
\text { training. }\end{array}$ \\
\hline$[52]$ & Upper arm & Robot hand & $\begin{array}{l}\text { A tactile } \\
\text { sensor with } \\
\text { conductive } \\
\text { rubber }\end{array}$ & $5 / 0$ & $\begin{array}{l}\text { Three vibrators } \\
\text { (VMT-003, } \\
\text { Yatsugatake } \\
\text { Club, } \varphi 11 \times \mathrm{t} 3 \\
\text { mm), one actuator } \\
\text { for each finger. }\end{array}$ & $\begin{array}{l}\text { The validation of the } \\
\text { haptic feedback } \\
\text { system to improve the } \\
\text { cognitive strain of the } \\
\text { upper prostheses that } \\
\text { associated with the } \\
\text { action of grasping an } \\
\text { object. }\end{array}$ \\
\hline$[53]$ & Upper arm & Robot hand & $\begin{array}{l}\text { Force sensory } \\
\text { system } \\
\text { mounted on } \\
\text { the fingertip }\end{array}$ & $9 / 4$ & $\begin{array}{c}\text { DC motor } \\
\text { (Maxon EC32, } \\
15 \mathrm{~W}) .\end{array}$ & $\begin{array}{l}\text { The feedback of the } \\
\text { tactile sensory system } \\
\text { is highly } \\
\text { recommended to } \\
\text { improve the } \\
\text { velocity/grasp force of } \\
\text { the EMG myoelectric } \\
\text { prosthetic hand. }\end{array}$ \\
\hline [54] & Upper arm & $\begin{array}{c}\text { Myoelectric } \\
\text { prosthetic } \\
\text { hand }\end{array}$ & $\begin{array}{l}\text { One FSR } 400 \\
\text { for the thumb } \\
\text { and two } \\
\text { FSR406 short } \\
\text { for the index } \\
\text { and middle } \\
\text { fingers }\end{array}$ & $0 / 5$ & $\begin{array}{l}\text { Two miniaturized } \\
\text { DC vibrating } \\
\text { motors (model } \\
\text { 306-101, } \\
\text { Precision } \\
\text { Microdrives Ltd, } \\
\text { London, UK) }\end{array}$ & $\begin{array}{l}\text { The effectiveness of } \\
\text { the designed wearable } \\
\text { device for controlling } \\
\text { the prosthetic hand in } \\
\text { daily life conditions } \\
\text { was demonstrated }\end{array}$ \\
\hline$[55]$ & Forearm & $\begin{array}{l}\text { Myoelectric } \\
\text { fully } \\
\text { controlled } \\
\text { artificial } \\
\text { hand }\end{array}$ & $\begin{array}{l}\text { Two thin } \\
\text { force sensors } \\
\text { (Flexiforce, } \\
\text { Tekscan Inc., } \\
\text { USA) }\end{array}$ & $46 / 0$ & $\begin{array}{l}\text { Elastic strap } \\
\text { containing eight } \\
\text { vibrotactile } \\
\text { actuators }\end{array}$ & $\begin{array}{c}\text { A longer training } \\
\text { period was } \\
\text { recommended when } \\
\text { integrating a } \\
\text { myoelectric controlled } \\
\text { hand with haptic } \\
\text { vibrotactile feedback } \\
\text { display }\end{array}$ \\
\hline [56] & Forearm & $\begin{array}{l}\text { The study } \\
\text { didn't } \\
\text { include an } \\
\text { artificial } \\
\text { hand }\end{array}$ & $\begin{array}{l}\text { The study } \\
\text { didn't include } \\
\text { an sensor }\end{array}$ & $9 / 0$ & $\begin{array}{l}\text { Three vibration } \\
\text { motors, each one } \\
\text { consists of a } \\
\text { miniaturized DC } \\
\text { motor (Precision } \\
\text { Microdrives, UK) }\end{array}$ & $\begin{array}{l}\text { All volunteers } \\
\text { discriminated three } \\
\text { amplitudes generated } \\
\text { from the proposed } \\
\text { device successfully }\end{array}$ \\
\hline [57] & Forearm & $\begin{array}{l}\text { The study } \\
\text { didn't } \\
\text { include an } \\
\text { artificial } \\
\text { hand }\end{array}$ & $\begin{array}{l}\text { The study } \\
\text { didn't include } \\
\text { an sensor }\end{array}$ & $10 / 0$ & $\begin{array}{l}\text { Two vibromotors } \\
\text { placed in one } \\
\text { line, with } 3 \mathrm{~cm} \\
\text { between each one }\end{array}$ & $\begin{array}{l}75 \% \text { of the } \\
\text { participants were able } \\
\text { to distinguish the } \\
\text { various forces exerted } \\
\text { by the haptic wearable } \\
\text { device }\end{array}$ \\
\hline [58] & Forearm & $\begin{array}{l}\text { The study } \\
\text { didn't } \\
\text { include an } \\
\text { artificial } \\
\text { hand }\end{array}$ & $\begin{array}{l}\text { The study } \\
\text { didn't include } \\
\text { an sensor }\end{array}$ & $4 / 0$ & $\begin{array}{l}\text { Four vibromotors } \\
\text { (two placed on } \\
\text { elbow join and } \\
\text { other two on wrist } \\
\text { joint) }\end{array}$ & $\begin{array}{l}\text { The users of the haptic } \\
\text { device are competent } \\
\text { to undergo the synergy } \\
\text { between different } \\
\text { sensory modalities that } \\
\text { can guide them to } \\
\text { perform simple tasks } \\
\text { with help of intuitive } \\
\text { tactile cues }\end{array}$ \\
\hline
\end{tabular}




\begin{tabular}{|c|c|c|c|c|c|c|}
\hline [59] & Upper limb & Virtual hand & Virtual sensor & $18 / 0$ & $\begin{array}{c}\text { A haptic sleeve } \\
\text { stimulators with } \\
\text { electromagnetic } \\
\text { motion } \\
\text { tracking system } \\
\text { (TrakSTAR, } \\
\text { Ascension } \\
\text { Technology, Inc., } \\
\$ 4,440 \text { ) }\end{array}$ & $\begin{array}{l}\text { There are no strong } \\
\text { differences in } \\
\text { performance between } \\
\text { attractive and } \\
\text { repulsive tactile } \\
\text { feedback }\end{array}$ \\
\hline [60] & Forearm & Virtual hand & Virtual sensor & $17 / 0$ & $\begin{array}{c}\text { Single tactor } \\
\text { vibrotactile } \\
\text { feedback actuator }\end{array}$ & $\begin{array}{l}\text { The combination of } \\
\text { haptic and visual } \\
\text { feedback does not } \\
\text { provide better results } \\
\text { than using the visual } \\
\text { feedback alone }\end{array}$ \\
\hline [61] & Upper arm & Virtual hand & Vitual sensor & $0 / 0$ & $\begin{array}{l}\text { The 304-111 Pico } \\
\text { VibeTM 5mm } \\
\text { vibration dc } \\
\text { motor }\end{array}$ & $\begin{array}{l}\text { The proposed haptic } \\
\text { device is very } \\
\text { important to provide } \\
\text { an efficient } \\
\text { supplementary } \\
\text { sensation to the user of } \\
\text { the prostheses }\end{array}$ \\
\hline [62] & $\begin{array}{l}\text { Fingertip, } \\
\text { foot, and } \\
\text { upper arm }\end{array}$ & Robot arm & Accelerometer & $5 / 0$ & $\begin{array}{l}\text { Three } \\
\text { vibromotors of } \\
\text { C2 tactor type }\end{array}$ & $\begin{array}{l}\text { The foot is a better } \\
\text { location for installing } \\
\text { the haptic vibrotactile } \\
\text { system because of its } \\
\text { sensitivity to haptic } \\
\text { stimuli }\end{array}$ \\
\hline [63] & Upper arm & $\begin{array}{l}\text { The study } \\
\text { didn't } \\
\text { include an } \\
\text { artificial } \\
\text { hand }\end{array}$ & $\begin{array}{l}\text { QTC pressure } \\
\text { sensors } \\
\text { with } 10 \mathrm{~mm} \\
\text { diameters }\end{array}$ & $10 / 0$ & $\begin{array}{c}\text { Seven LRA } \\
\text { vibration motors }\end{array}$ & $\begin{array}{l}\text { The volunteers were } \\
\text { able to detect the } \\
\text { contact pressure and } \\
\text { the surface texture } \\
\text { with high accuracy } \\
\text { simultaneously }\end{array}$ \\
\hline [64] & Forearm & Virtual hand & Virtual sensor & $10 / 0$ & $\begin{array}{c}\text { A DC motor } \\
\text { vibrotactile tactor } \\
\text { of } 78 \times 33 \times 24 \\
\mathrm{~mm} 3 \text { final } \\
\text { dimantion }\end{array}$ & $\begin{array}{l}\text { All subjects were able } \\
\text { to discriminate the } \\
\text { slippage successfully } \\
\text { based on the designed } \\
\text { device }\end{array}$ \\
\hline
\end{tabular}

\subsection{Skin Stretch Feedback Display}

The skin stretch feedback display is another mechanism of local skin deformation, depends on scratching the skin to provide the tactile data to amputees with the haptic upper limb prostheses [65]. A brief summary of the previous works that investigated how to use the skin stretch feedback display to excite the skin of the haptic prostheses users was listed in Table 3. A haptic skin stretch wearable device, called Haptic Rocker, has been designed to convey useful information of the size of the grasped objects in [66]. The haptic device was mounted on the patient's upper arm. It consists of a frame, strap, rocker, and servomotor, as described in Fig. 6. A. The wearable device was integrated with 19 DoFs Pisa/IIT SoftHand to perform the experimental functionality tests. The results showed that the skin stretch haptic system was able to recognize the objects' shapes successfully, with an average accuracy of $73.3 \pm 11.2 \%$. In a similar study, HapPro wearable device of $75 \mathrm{~g}$ total weight was designed [67]. The main idea of the haptic device is to enable a cart to slide linearly over the skin of the forearm, in order to convey the sensation of the objects' size to the user of the prosthetic hand, as shown in Fig. 6. B. A DC motor (Pololu 298:1 Micro Metal Gearmotor) was employed as the mechanical power source, in which the rotational movement can be transformed to a linear movement by mean of pulley system. The experimental tests on 43 healthy participants and one amputee subject confirmed that the HapPro wearable device is an effective device for exciting the patients' brain. 
(A)

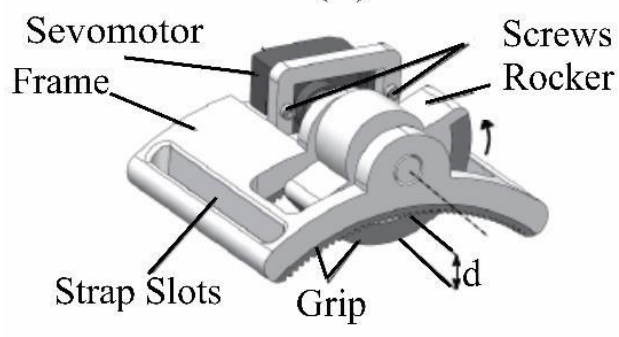

(B)

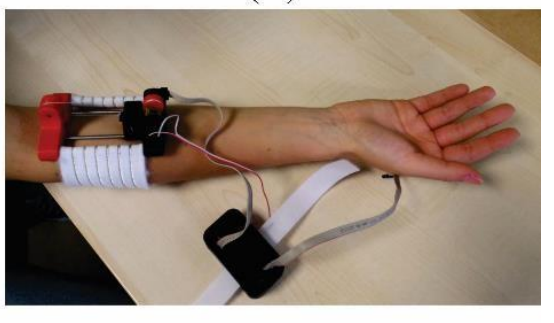

Fig. 6 - The Haptic Rocker skin stretch wearable device: A) The Haptic Rocker CAD model [66]. B) The HapPro wearable device [67].

On the other hand, a new skin stretch mechanoreceptors wearable device has been designed to discriminate the position and motion of the upper limb prostheses through sensing the rotational stretch on the skin of the upper residual arm [68-70]. The device was designed from two $14 \mathrm{~mm}$ circular end effector driven by an ultrasonic piezoelectric motor (Shinsei Motor, USR30-B3). The end effectors were able to excite the skin with 0.6 N.m effecting torque. The evaluation experiments on able-bodied subjects indicated that, the device has significant benefit for recovery the sensation when integrated with the myoelectric prosthetic hand. However, few hours of training were highly recommended. Other haptic skin stretch techniques were presented in [71-73]. The wearable device was designed with four independent cylindrical end effectors driven by four servo motors. The lightweight device was installed on the subjects' forearm to allow the end effectors stretch the skin at the palmar, dorsal, ulnar, and radial sides of the arm. The main aim of such wearable devices is to navigate the robotic arms by controlling the position and the orientation of the robotics' end effectors with a complete absence of any visual information.

Table 3 - Summary of the articles that dealt with the skin stretch feedback display.

\begin{tabular}{|c|c|c|c|c|c|c|}
\hline Ref. & $\begin{array}{l}\text { Location } \\
\text { of the } \\
\text { feedback } \\
\text { display }\end{array}$ & $\begin{array}{l}\text { Type of the } \\
\text { artificial } \\
\text { hand }\end{array}$ & $\begin{array}{l}\text { Type of the } \\
\text { sensory } \\
\text { system }\end{array}$ & $\begin{array}{l}\text { No of healthy } \\
\text { volunteers / } \\
\text { No of } \\
\text { amputees } \\
\text { volunteers }\end{array}$ & $\begin{array}{l}\text { The details of the } \\
\text { using stimulator }\end{array}$ & $\begin{array}{l}\text { Finding and } \\
\text { conclusion }\end{array}$ \\
\hline [65] & Forearm & $\begin{array}{l}\text { Virtual } \\
\text { hand }\end{array}$ & $\begin{array}{l}\text { Virtual tactile } \\
\text { sensory } \\
\text { system }\end{array}$ & $11 / 0$ & $\begin{array}{c}\text { Three DOF } \\
\text { wearable device } \\
\text { with two motors } \\
\text { and two bracelets }\end{array}$ & $\begin{array}{l}\text { The haptic device still } \\
\text { needs further } \\
\text { improvement because } \\
\text { there is some confusion } \\
\text { when sending the } \\
\text { tactile information }\end{array}$ \\
\hline [66] & Upper arm & $\begin{array}{l}\text { Pisa/IIT } \\
\text { SoftHand } \\
\text { with } 19 \\
\text { DoFs }\end{array}$ & $\begin{array}{l}\text { Position } \\
\text { sensors }\end{array}$ & $8 / 0$ & $\begin{array}{l}\text { Haptic Rocker } \\
\text { consists of a } \\
\text { frame, strap, } \\
\text { rocker, and servo }\end{array}$ & $\begin{array}{l}\text { The skin stretch haptic } \\
\text { system was able to } \\
\text { recognize the objects' } \\
\text { shapes successfully, } \\
\text { with an average } \\
\text { accuracy of } \\
73.3 \pm 11.2 \%\end{array}$ \\
\hline [67] & Forearm & $\begin{array}{l}\text { Pisa/IIT } \\
\text { SoftHand } \\
\text { with } 19 \\
\text { DoFs }\end{array}$ & $\begin{array}{l}\text { Position } \\
\text { sensors }\end{array}$ & $43 / 1$ & $\begin{array}{l}\text { HapPro wearable } \\
\text { device, total } \\
\text { weight of } 75 \mathrm{~g} \\
\text { structured from a } \\
\text { cart that can slide } \\
\text { lineary over the } \\
\text { skin of the } \\
\text { forearm }\end{array}$ & $\begin{array}{l}\text { The HapPro wearable } \\
\text { device is an effective } \\
\text { device to excite the } \\
\text { patients' brain }\end{array}$ \\
\hline $\begin{array}{l}{[68,} \\
69]\end{array}$ & Upper arm & $\begin{array}{l}\text { The study } \\
\text { didn't } \\
\text { include an } \\
\text { artificial } \\
\text { hand }\end{array}$ & $\begin{array}{l}\text { The study } \\
\text { didn't include } \\
\text { any sensor }\end{array}$ & $10 / 0$ & $\begin{array}{l}\text { The device was } \\
\text { designed from } \\
\text { two } 14 \mathrm{~mm} \\
\text { circular end } \\
\text { effector driven by } \\
\text { an ultrasonic } \\
\text { piezoelectric }\end{array}$ & $\begin{array}{l}\text { The device has } \\
\text { significant benefit for } \\
\text { recovery the sensation } \\
\text { when integrated with } \\
\text { the myoelectric } \\
\text { prosthetic hand. } \\
\text { however, few hours of }\end{array}$ \\
\hline
\end{tabular}




\begin{tabular}{|c|c|c|c|c|c|c|}
\hline & & & & & $\begin{array}{l}\text { motor (Shinsei } \\
\text { Motor, USR30- } \\
\text { B3) }\end{array}$ & $\begin{array}{l}\text { training were highly } \\
\text { recommended }\end{array}$ \\
\hline [70] & Upper arm & $\begin{array}{l}\text { The study } \\
\text { didn't } \\
\text { include an } \\
\text { artificial } \\
\text { hand }\end{array}$ & $\begin{array}{l}\text { The study } \\
\text { didn't include } \\
\text { any sensor }\end{array}$ & $15 / 0$ & $\begin{array}{l}\text { The device was } \\
\text { designed from } \\
\text { two } 14 \mathrm{~mm} \\
\text { circular end } \\
\text { effector driven by } \\
\text { an ultrasonic } \\
\text { piezoelectric } \\
\text { motor (Shinsei } \\
\text { Motor, USR30- } \\
\text { B3) }\end{array}$ & $\begin{array}{l}\text { Increasing the range of } \\
\text { rotation of the end } \\
\text { effectors leads to } \\
\text { improved performance } \\
\text { of the wearable device. } \\
\text { However, the device } \\
\text { shall not be used for } \\
\text { more than } 2 \text { hours }\end{array}$ \\
\hline [71] & Forearm & $\begin{array}{l}\text { The study } \\
\text { didn't } \\
\text { include an } \\
\text { artificial } \\
\text { hand }\end{array}$ & $\begin{array}{c}\text { A six-axis } \\
\text { force/torque } \\
\text { sensor (ATI } \\
\text { Nano } \\
25, \text { ATI } \\
\text { Industrial } \\
\text { Automation, } \\
\text { USA) } \\
\end{array}$ & $10 / 0$ & $\begin{array}{l}\text { Four independent } \\
\text { cylindrical end } \\
\text { effectors driven } \\
\text { by four servo } \\
\text { motors }\end{array}$ & $\begin{array}{l}\text { The participants } \\
\text { recorded an average } \\
\text { error of } 1.87 \text { and } 2.84 \\
\text { mm for rotation and } \\
\text { transition navigation, } \\
\text { respectively. }\end{array}$ \\
\hline [72] & Forearm & $\begin{array}{c}\text { 6-DoF } \\
\text { robotic } \\
\text { manipulator }\end{array}$ & $\begin{array}{c}\text { Four } \\
\text { piezoresistive } \\
\text { Force } \\
\text { Sensing } \\
\text { Resistor } \\
\text { (FSR) }\end{array}$ & $10 / 0$ & $\begin{array}{l}\text { Four independent } \\
\text { cylindrical end } \\
\text { effectors driven } \\
\text { by four servo } \\
\text { motors }\end{array}$ & $\begin{array}{l}\text { The non-effectively of } \\
\text { using the proposed } \\
\text { wearable device for } \\
\text { feedback the tactile } \\
\text { information instead of } \\
\text { visual feedback to } \\
\text { navigate the robotic } \\
\text { arm is the main } \\
\text { conclusion of the study }\end{array}$ \\
\hline [73] & Forearm & $\begin{array}{l}\text { The study } \\
\text { didn't } \\
\text { include an } \\
\text { artificial } \\
\text { hand }\end{array}$ & $\begin{array}{l}\text { ATI Nano17 } \\
\text { force sensor }\end{array}$ & $12 / 0$ & $\begin{array}{l}\text { Four independent } \\
\text { cylindrical end } \\
\text { effectors driven } \\
\text { by four servo } \\
\text { motors }\end{array}$ & $\begin{array}{l}\text { The preferable } \\
\text { perceptual performance } \\
\text { of the independent skin } \\
\text { stretch device occurs } \\
\text { when the center of } \\
\text { curvature located } \\
\text { coincident or above the } \\
\text { center of rotation }\end{array}$ \\
\hline
\end{tabular}

\subsection{Squeeze Feedback Display}

The squeeze feedback display is highly portable devices based on using an elastic fabric band to move forward and backward over the user residual part, thus simulating a human caress by means of squeezing it [74-79]. The main works which associate with this haptic feedback technique are listed in Table 4.

Comparison between the native hand and the prosthetic hand associated with grasping objects and discriminating its size was briefly investigated in [74, 75], in order to create alternative cutaneous stimulation to the amputees of upper arm mutilation, with high performance and a reliable manner The Clenching Upper-limb Force Feedback device (CUFF) in blending with the Soft Hand Pro (SHP), an anthropomorphic, EMG prosthetic controller are used to grasp and release the objects of different sizes and weights. The researcher validated the inspection truth and concluded that, in general, the real hand uses less force and energy than CUFF and SHF. However, at the same time, the functionality of equipping SHF with the sensing system over the SHF alone has been verified by controlling the prosthetic hand without utilizing the force sensors. Broadly, this type of haptic feedback technology is very effective in conveying sensory information and improving the performance of the myoelectric prosthetic arm in the complete absence of visual vision [76, 77].

A novel squeeze feedback wearable device was designed to simulate a human caress [78]. The device consists of a rectangular-shaped fabric $(60 \mathrm{~mm} \times 160 \mathrm{~mm})$ driven by two rolls, each of roll moved by one DC motor (HITEC digital DC servo motor HS-7954 H with an input voltage of 7.4 V), as shown in Fig. 7. The rectangular-shaped fabric moves with a sliding motion around the forearm of the subject. The variation of the movement's velocity and the movement's strength give the subject the sensation of the caress-like. The evaluation experiments validated the ability of the haptic device to elicit tactually emotional states in humans. On the other side, the same technique has been used to control the 
grasping force of the upper limb prosthesis, in order to enable the amputees to apply a suitable grasp strength force on the objects, s to prohibit smashing objects in the palm of the hand and to prevent object slipping [79].

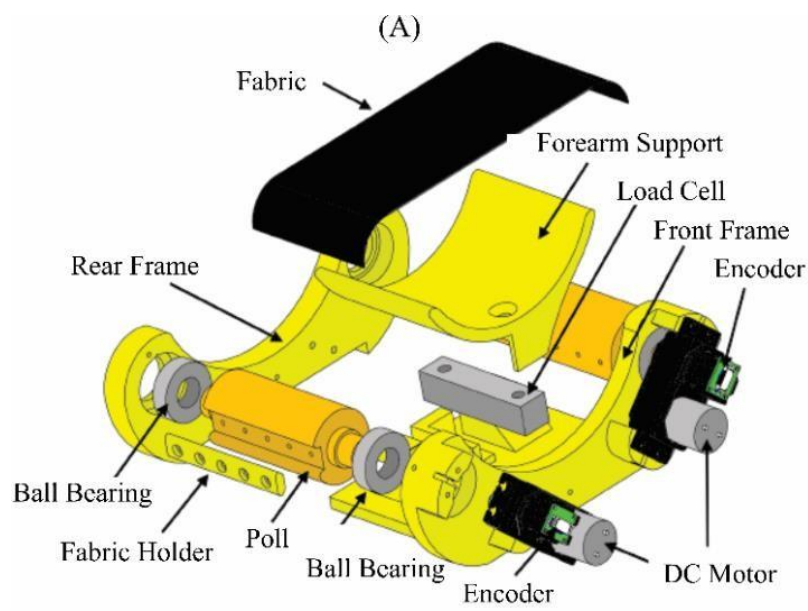

(B)

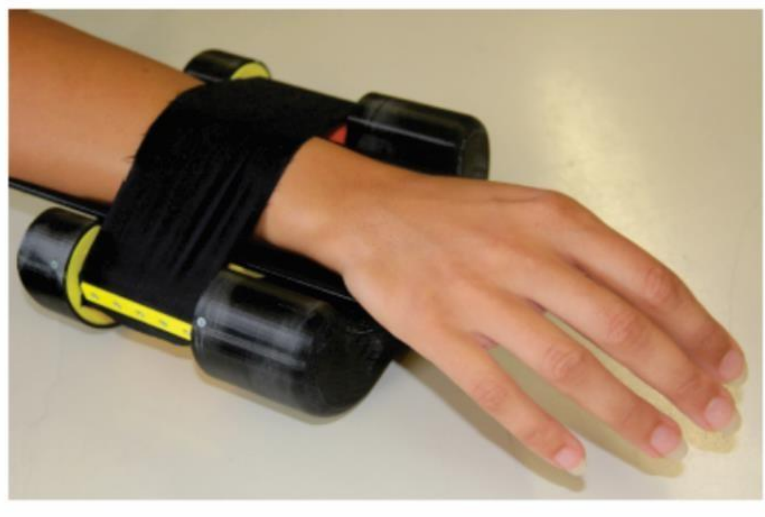

Fig. 7 - The squeeze feedback stimulation device: A) The 3D drawing view of the device's design conception. B) The participant wore the device on the forearm of his right hand.

Table 4 - Summary of the articles that dealt with the squeeze feedback display.

\begin{tabular}{|c|c|c|c|c|c|c|}
\hline Ref. & $\begin{array}{l}\text { Location } \\
\text { of the } \\
\text { feedback } \\
\text { display }\end{array}$ & $\begin{array}{l}\text { Type of the } \\
\text { artificial } \\
\text { hand }\end{array}$ & $\begin{array}{l}\text { Type of the } \\
\text { sensory } \\
\text { system }\end{array}$ & $\begin{array}{l}\text { No of healthy } \\
\text { volunteers / } \\
\text { No of } \\
\text { amputees } \\
\text { volunteers }\end{array}$ & $\begin{array}{l}\text { The details of the } \\
\text { using stimulator }\end{array}$ & $\begin{array}{l}\text { Finding and } \\
\text { conclusion }\end{array}$ \\
\hline $\begin{array}{l}{[74,} \\
75]\end{array}$ & Upper arm & $\begin{array}{c}\text { The } \\
\text { Pisa/IIT } \\
\text { Soft Hand }\end{array}$ & $\begin{array}{l}\text { Position } \\
\text { sensors }\end{array}$ & $6 / 1$ & $\begin{array}{l}\text { Clenching Upper- } \\
\text { limb Force } \\
\text { Feedback device } \\
\text { (CUFF) }\end{array}$ & $\begin{array}{l}\text { Equipping SHF with } \\
\text { the tactile position } \\
\text { sensors is an effective } \\
\text { alternative method to } \\
\text { using the tactile force } \\
\text { sensors }\end{array}$ \\
\hline [76] & Upper arm & $\begin{array}{l}\text { The study } \\
\text { didn't } \\
\text { include an } \\
\text { artificial } \\
\text { hand }\end{array}$ & $\begin{array}{l}\text { The study } \\
\text { didn't include } \\
\text { any sensor }\end{array}$ & $6 / 0$ & $\begin{array}{c}\text { A squeeze band } \\
\text { wearable device } \\
\text { driven by a } \\
\text { servomotor, } \\
\text { weighing } 3.8 \mathrm{oz} \text {. }\end{array}$ & $\begin{array}{l}\text { Volunteers are capable } \\
\text { to react to the } \\
\text { presented cues through } \\
\text { the squeeze band in the } \\
\text { compensative tracking } \\
\text { function }\end{array}$ \\
\hline \begin{tabular}{l|l}
$77]$ \\
\end{tabular} & Upper arm & $\begin{array}{l}\text { Myoelectric } \\
\text { prosthetic } \\
\text { hand }\end{array}$ & $\begin{array}{l}\text { (FSR402 } \\
\text { short tail) }\end{array}$ & $1 / 0$ & $\begin{array}{c}\text { A small size } \\
\text { wearable squeeze } \\
\text { device with } \\
\text { dimention } 97 \mathrm{~W} x \\
117 \mathrm{D} \mathrm{x} 39 \mathrm{H} \\
(\mathrm{mm})\end{array}$ & $\begin{array}{l}\text { The effectiveness of } \\
\text { the haptic feedback } \\
\text { stimulation device to } \\
\text { convey the contact } \\
\text { pressure was shown }\end{array}$ \\
\hline [78] & Forearm & $\begin{array}{l}\text { The study } \\
\text { didn't } \\
\text { include an } \\
\text { artificial } \\
\text { hand }\end{array}$ & $\begin{array}{l}\text { The study } \\
\text { didn't include } \\
\text { any sensor }\end{array}$ & $6 / 0$ & $\begin{array}{c}\text { A rectangular- } \\
\text { shaped fabric (60 } \\
\mathrm{mm} \times 160 \mathrm{~mm}) \\
\text { driven by two } \\
\text { rolls, where each } \\
\text { of roll was moved } \\
\text { by one HITEC } \\
\text { digital DC motor }\end{array}$ & $\begin{array}{l}\text { The evaluation } \\
\text { experiments validated } \\
\text { the ability of the haptic } \\
\text { device to elicit } \\
\text { tactually emotional } \\
\text { states in humans }\end{array}$ \\
\hline [79] & forearm & $\begin{array}{l}\text { The study } \\
\text { didn't } \\
\text { include an } \\
\text { artificial } \\
\text { hand }\end{array}$ & $\begin{array}{c}\text { Force } \\
\text { sensitive } \\
\text { resistor (FSR) }\end{array}$ & $10 / 0$ & $\begin{array}{c}\text { A wearable } \\
\text { single-actuator } \\
\text { haptic device }\end{array}$ & $\begin{array}{l}\text { The proposed device is } \\
\text { able to display normal } \\
\text { forces and the slip } \\
\text { speed in a quiet manner } \\
\text { and high accuracy }\end{array}$ \\
\hline
\end{tabular}




\subsection{Electro Feedback Display}

The electro feedback display is the haptic method of delivering low-level electrical current pulses to the user's skin in order to depolarize skin afferents, thereby eliciting the haptic sensation [80]. The electro feedback stimulators are usually formed from a single row of activating electrode pads [81-83] or from matrix patterns [80, 84]. This is due to the distribution of the electrode pads is completely depending on the design of the haptic system and the nature of the measured signal of the sensory system. Table 5 presents a short survey of the studies in electro feedback display.

The ability of the electro haptic feedback stimulation system to help the amputees to detect the contact pressure and the surface texture at the same operation time was investigated in [34]. For this reason, a lightweight vibration sensor was attached to the artificial sensor in order to sense the texture of the plastic, sand, rice, and matchsticks surfaces. Different surfaces were arranged over a textured rotatable platter and the artificial finger was allowed to slide freely over it. During the experiment, the main function of the electro feedback stimulator is to provide a wide range of frequencies to the users about the contact pressure and the surface texture in a way that the tactile information can be clearly distinguished by the users. The evaluation tests showed that all the engaged volunteers were able to detect the contact pressure successfully without brain confusion. The volunteers recorded around $75 \%$ average discrimination accuracy at the surface texture detection tests.

The feasibility of recovering the touch sensation from prosthetic fingertip based on the evoked tactile sensation (ETS) was demonstrated in $[85,86]$. The transcutaneous electrical nerve stimulation (TENS) electro feedback system was used to stimulate patient's skin and convey the tactile information to his brain. In addition, the functionality of the electro stimulators to relocate the sensation of the tickling, contact pressure, and pain during touching and grasping objects was investigated [87]. The experimental setup was divided into two main loops: feed-forward, and feed-backward loops, as shown in Fig. 8. Controlling the movement and the performance of the 3D prosthetic hand model prosthetic hand by using EMG signals are the feed-forward loop. The feed-backward loop represents the haptic feedback stimulation system, in which the contact pressure at the prosthetic hand is measured by the pressure sensors and restored to the user by two electro displays attached at the user's forearm. The results validated the efficacy of the electro feedback stimulators to convey the tactile information in a quick manner. Furthermore, the effectiveness of the suggested hybrid closed-loop controller that integrated with the upper limb prostheses to enhance the operation efficiency and accuracy for crisp objects has been shown [88].

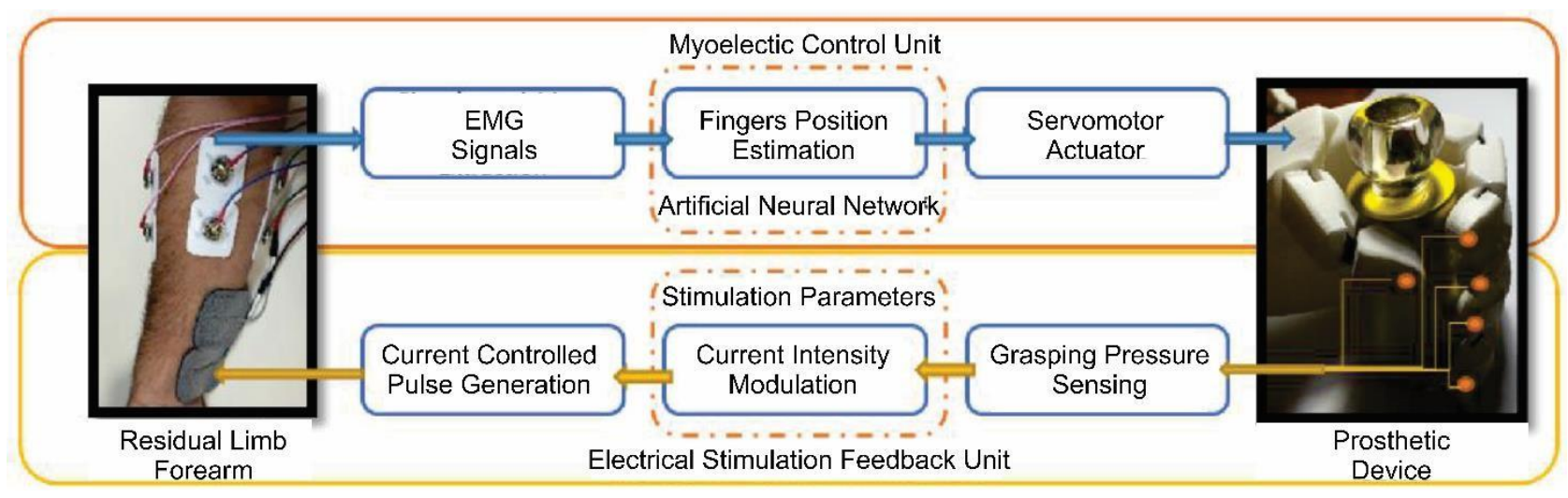

Fig. 8 - The controlling loops of the 3D prosthetic hand model prosthetic hand [87].

Table 5 - Summary of the articles that dealt with the electro feedback display.

\begin{tabular}{|c|c|c|c|c|c|c|}
\hline Ref. & $\begin{array}{c}\text { Location } \\
\text { of the } \\
\text { feedback } \\
\text { display }\end{array}$ & $\begin{array}{c}\text { Type of the } \\
\text { artificial hand }\end{array}$ & $\begin{array}{c}\text { Type of the } \\
\text { sensory } \\
\text { system }\end{array}$ & $\begin{array}{c}\text { No of } \\
\text { healthy } \\
\text { volunteers } \\
\text { / No of } \\
\text { amputees } \\
\text { volunteers }\end{array}$ & $\begin{array}{c}\text { The details of } \\
\text { the using } \\
\text { stimulator }\end{array}$ & $\begin{array}{c}\text { Finding and } \\
\text { conclusion }\end{array}$ \\
\hline$[80]$ & Forearm & $\begin{array}{c}\text { The study didn't } \\
\text { include an } \\
\text { artificial hand }\end{array}$ & $\begin{array}{c}\text { The study } \\
\text { didn't } \\
\text { include an } \\
\text { sensor }\end{array}$ & $8 / 0$ & $\begin{array}{c}\text { MaxSens } \\
\text { stimulator } \\
\text { electrodes }\end{array}$ & $\begin{array}{c}\text { All volunteers were } \\
\text { capable to recognize } \\
\text { different shapes, } \\
\text { with recognition } \\
\text { accuracy of } 86 \pm 8 \% \\
\text { for lines, } 73 \pm 13 \% \\
\text { for geometries, } \\
72 \pm 12 \% \text { for letters }\end{array}$ \\
\hline
\end{tabular}




\begin{tabular}{|c|c|c|c|c|c|c|}
\hline $\begin{array}{l}{[81,} \\
82]\end{array}$ & Forearm & $\begin{array}{l}\text { Michelangelo } \\
\text { hand prosthesis } \\
\text { (Otto Bock } \\
\text { Healthcare } \\
\text { GmbH, Vienna, } \\
\text { AT) } \\
\end{array}$ & $\begin{array}{l}\text { Force sensor } \\
\quad \text { (strain } \\
\text { gauge) }\end{array}$ & $0 / 9$ & $\begin{array}{c}\text { MaxSens } \\
\text { stimulator } \\
\text { (Tecnalia } \\
\text { Research and } \\
\text { Innovation, San } \\
\text { Sebastian, ES) } \\
\end{array}$ & $\begin{array}{l}\text { The electro feedback } \\
\text { stimulation system } \\
\text { was able to improve } \\
\text { the performance of } \\
\text { the prostheses }\end{array}$ \\
\hline [83] & Forearm & Virtual hand & $\begin{array}{l}\text { Virtual } \\
\text { tactile } \\
\text { sensory } \\
\text { system }\end{array}$ & $8 / 0$ & $\begin{array}{c}\text { Multipad } \\
\text { electrode was } \\
\text { placed around the } \\
\text { user's forearm }\end{array}$ & $\begin{array}{l}\text { The visual feedback } \\
\text { and the tactile } \\
\text { feedback have the } \\
\text { similar performance } \\
\text { during routine } \\
\text { grasping. }\end{array}$ \\
\hline [84] & Forearm & $\begin{array}{l}\text { The study didn't } \\
\text { include an } \\
\text { artificial hand }\end{array}$ & $\begin{array}{l}\text { Piezoelectric } \\
\text { polymer } \\
\text { sensors }\end{array}$ & $5 / 0$ & $\begin{array}{l}\text { Tecnalia Int FES } \\
\text { stimulator }\end{array}$ & $\begin{array}{l}\text { Participants detected } \\
\text { different touch } \\
\text { forces with } \\
\text { satisfactory success } \\
\text { rate }\end{array}$ \\
\hline [34] & Hand & Robotic Finger & $\begin{array}{l}\text { Vibration } \\
\text { sensor }\end{array}$ & $5 / 0$ & $\begin{array}{l}\text { TENS electrodes } \\
\text { were fitted to the } \\
\text { user's } \\
\text { hand }\end{array}$ & $\begin{array}{l}\text { All the engaged } \\
\text { volunteers detected } \\
\text { the contact pressure } \\
\text { successfully, and the } \\
\text { volunteers recorded } \\
\text { around } 75 \% \text { average } \\
\text { discrimination } \\
\text { accuracy at the } \\
\text { surface texture } \\
\text { detection tests. }\end{array}$ \\
\hline $\begin{array}{l}{[85,} \\
86]\end{array}$ & Forearm & Prosthetic hand & $\begin{array}{l}\text { force- } \\
\text { sensing- } \\
\text { resistor } \\
\text { (FSR) } \\
\text { pressure } \\
\text { transducers }\end{array}$ & $0 / 2$ & $\begin{array}{l}\text { Phenomenon of } \\
\text { evoked tactile } \\
\text { sensation (ETS) } \\
\text { using } \\
\text { transcutaneous } \\
\text { electric nerve } \\
\text { stimulation } \\
\text { (TENS) }\end{array}$ & $\begin{array}{l}\text { The feasibility of } \\
\text { recovering the } \\
\text { pressure sensation } \\
\text { from prosthetic } \\
\text { fingertip based on } \\
\text { the evoked tactile } \\
\text { sensation (ETS) has } \\
\text { been demonstrated }\end{array}$ \\
\hline [87] & Forearm & $\begin{array}{l}\text { 3D Prosthetic } \\
\text { Hand Model } \\
\text { with Linear } \\
\text { Actuators }\end{array}$ & $\begin{array}{l}\text { Flexion } \\
\text { pressure } \\
\text { sensor }\end{array}$ & $5 / 0$ & $\begin{array}{c}\text { Two } \\
\text { transcutaneous } \\
\text { electrical } \\
\text { stimulation }\end{array}$ & $\begin{array}{l}\text { The results showed } \\
\text { the efficacy of the } \\
\text { electro feedback } \\
\text { stimulators to } \\
\text { convey the tactile } \\
\text { information in a } \\
\text { quick manner }\end{array}$ \\
\hline [88] & Forearm & $\begin{array}{l}\text { HIT-IV hand, } \\
\text { 5-DOF } \\
\text { anthropomorphic } \\
\text { prosthetic hand }\end{array}$ & $\begin{array}{l}\text { Position and } \\
\text { torque } \\
\text { sensors }\end{array}$ & $8 / 2$ & $\begin{array}{l}\text { Transcutaneous } \\
\text { electric nerve } \\
\text { stimulation } \\
\text { (TENS) }\end{array}$ & $\begin{array}{l}\text { The effectiveness of } \\
\text { the suggested hybrid } \\
\text { closed-loop } \\
\text { controller that } \\
\text { integrated with the } \\
\text { upper limb } \\
\text { prostheses to } \\
\text { enhance the } \\
\text { operation efficiency } \\
\text { and accuracy for } \\
\text { crisp objects has } \\
\text { been established. }\end{array}$ \\
\hline $\begin{array}{l}89] \\
{[90]}\end{array}$ & Forearm & $\begin{array}{l}\text { Michelangelo } \\
\text { hand }\end{array}$ & $\begin{array}{l}\text { Virtual } \\
\text { tactile } \\
\text { sensory } \\
\text { system }\end{array}$ & $11 / 0$ & $\begin{array}{l}\text { Multichannel } \\
\text { stimulation unit } \\
\text { RehaStim }\end{array}$ & $\begin{array}{l}\text { The effectiveness of } \\
\text { using the electro } \\
\text { feedback display } \\
\text { with the prosthetic } \\
\text { hand was proven }\end{array}$ \\
\hline
\end{tabular}




\begin{tabular}{|c|c|c|c|c|c|c|}
\hline [91] & Forearm & $\begin{array}{l}\text { The study didn't } \\
\text { include an } \\
\text { artificial hand }\end{array}$ & $\begin{array}{l}\text { The study } \\
\text { didn't } \\
\text { include } \\
\text { sensor }\end{array}$ & $1 / 0$ & $\begin{array}{l}\text { Stimulation } \\
\text { electrode }\end{array}$ & $\begin{array}{l}\text { The evaluation tests } \\
\text { with able-body } \\
\text { subjects verified the } \\
\text { feasibility of the } \\
\text { proposed haptic } \\
\text { technique }\end{array}$ \\
\hline [92] & Upper arm & $\begin{array}{l}\text { The study didn't } \\
\text { include an } \\
\text { artificial hand }\end{array}$ & $\begin{array}{l}\text { The study } \\
\text { didn't } \\
\text { include } \\
\text { sensor }\end{array}$ & $6 / 6$ & $\begin{array}{l}\text { Multi- } \\
\text { channel } \\
\text { stimulation } \\
\text { electrode }\end{array}$ & $\begin{array}{l}\text { The slip feedback is } \\
\text { better than pressure } \\
\text { feedback. The } \\
\text { hybrid pressure and } \\
\text { slips feedback were } \\
\text { able to improve the } \\
\text { grasping rapidity }\end{array}$ \\
\hline [93] & Forearm & $\begin{array}{l}\text { Michelangelo } \\
\text { hand }\end{array}$ & $\begin{array}{l}\text { Virtual } \\
\text { tactile } \\
\text { sensory } \\
\text { system }\end{array}$ & $0 / 3$ & $\begin{array}{l}\text { Array of } 16 \\
\text { circular electro } \\
\text { stimulator }\end{array}$ & $\begin{array}{l}\text { The accuracy of the } \\
\text { force control is } \\
\text { increased when the } \\
\text { electro feedback is } \\
\text { used }\end{array}$ \\
\hline [94] & Forearm & $\begin{array}{l}\text { The study didn't } \\
\text { include an } \\
\text { artificial hand }\end{array}$ & $\begin{array}{l}\text { The study } \\
\text { didn't } \\
\text { include } \\
\text { sensor }\end{array}$ & $0 / 6$ & $\begin{array}{l}\text { Two directions of } \\
\text { electrodes } \\
\text { stimulator }\end{array}$ & $\begin{array}{l}\text { A moderate-size } \\
\text { electrode with stable } \\
\text { sensory modalities } \\
\text { was preferred for } \\
\text { transcutaneous } \\
\text { electrical nerve } \\
\text { stimulation }\end{array}$ \\
\hline [95] & Upper arm & $\begin{array}{l}\text { The study didn't } \\
\text { include an } \\
\text { artificial hand }\end{array}$ & $\begin{array}{l}\text { Virtual } \\
\text { sensory } \\
\text { system }\end{array}$ & $9 / 2$ & $\begin{array}{c}\text { Electrical } \\
\text { stimulation } \\
\text { device }\end{array}$ & $\begin{array}{l}\text { The intact skin areas } \\
\text { without phantom } \\
\text { sensations can } \\
\text { replace somatotopic } \\
\text { feedback sites } \\
\text { effectively }\end{array}$ \\
\hline
\end{tabular}

\subsection{Thermal Feedback Display}

The thermal feedback display is the method of conveying the thermal information of the grasping objects to the amputees of upper limb mutilation. Thus, the amputees will be able to recognize multi-information about the surfaces and bodies by depending on the difference in temperatures and the heat flux between the objects and the tactile prosthetic hand. Indeed, there are different geometrical properties of each material, such as heat capacity and thermal conductivity that affect directly on the thermal feeling. For example, a healthy human can distinguish between two objects of different material located in the same environment, i.e. both objects have the same temperature[96]. Therefore, this type of haptic display is called thermal feedback display but not temperature feedback display, because the feeling is depending on the object's thermal properties but not only on its temperature degree. Table 6 lists the works in thermal feedback display.

An extensive study associated with helping the amputees to recover the thermal sensation in high response and accuracy was presented in $[97,98]$. The main objective of these studies is to restore the thermal sensation by using low price equipment and solve its technical problems. Firstly, the low response problem of the K type (AD-1214) thermocouple temperature sensor was solved by proposing a new temperature prediction algorithm technique, in which the temperature can be estimated within few seconds. Secondly, the thermocouple temperature sensor with the temperature prediction algorithm technique was used to control the temperature of the rectangular Peltier element, which is a semiconductor device with two faces, and is competent to transfer heat flux from one side to the other. Consequently, the instability behavior of the Peltier element, especially when the operation time exceeds $5 \mathrm{sec}$, was analyzed. The evaluation experiment of the thermal feedback stimulation device has been conducted with ten healthy volunteers, myoelectric prosthetic hand, and five levels of temperature variations. The five temperature levels are: hot (approximately $40^{\circ} \mathrm{C}$ ), lukewarm (approximately $35{ }^{\circ} \mathrm{C}$ ), not much $\left(25{ }^{\circ} \mathrm{C}-30{ }^{\circ} \mathrm{C}\right.$ ), a little cold (approximately $20{ }^{\circ} \mathrm{C}$ ), and cold (approximately $15^{\circ} \mathrm{C}$ ). For ten participants, the temperature distinction evaluation tests achieved the average success rate of $88 \%$.

The main issue of the Peltier element is that high respone time is required when changing its surfaces from warm state to the cool state or vice versa. Therefore, four Peltier devices have been arranged in a matrix form[99, 100], as discribed in Fig. 9. Thus, the elements were configurated to enable rapid temporal change of temperature, since each of two opposite elements was programmed to work independently, with two elements for cooling the skin and the other two elements were utilized for the warming sensation. Two thermistor temperature sensors were used to build a feedback 
control loop, in order to control the temperature of the Peltier elements and inhibit over cooling and warming during thermal feedback. The recognition time of variation of temperature was improved by $36 \%$ on average, in comparison with using one Peltier element.

(a)

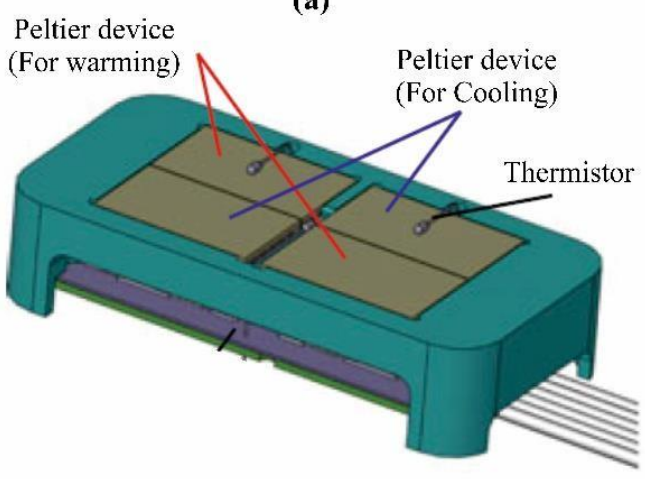

(b)

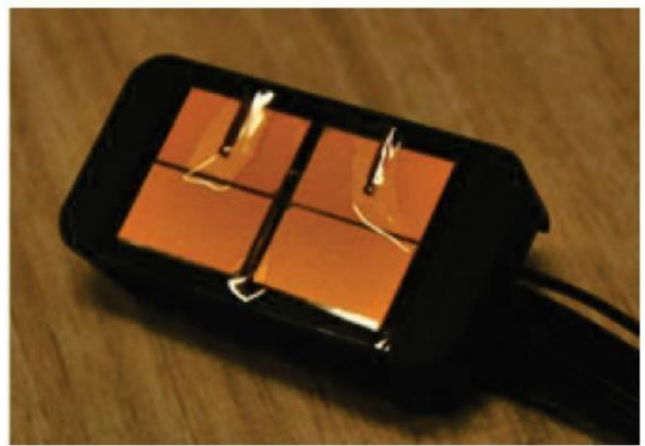

Fig. 9 - The haptic thermal feedback display: (a) The design conception. (b) The real device [100].

Finally, a novel Thermo-tactile Multimodal Display was designed and developed [101]. The haptic device consists of a Peltier cell with two heat exchangers attached on its surfaces, for cooling down and warming up the water and collecting it in two separated containers. The warm and cool water were pumped to the haptic device and mixed together in different proportions to convey the required thermal sensation to the skin of user. The device was designed to provide temperature sensation within the range of $20^{\circ} \mathrm{C}$ to $40^{\circ} \mathrm{C}$. Consequently, the evaluation results concluded that the design concept of the haptic device with very high-temperature variations response allows it to simulate the contact with many bodies found in our daily environment.

Table 6 - Summary of the articles that dealt with the thermal feedback display.

\begin{tabular}{|c|c|c|c|c|c|c|}
\hline Ref. & $\begin{array}{l}\text { Location } \\
\text { of the } \\
\text { feedback } \\
\text { display }\end{array}$ & $\begin{array}{l}\text { Type of } \\
\text { the } \\
\text { artificial } \\
\text { hand }\end{array}$ & $\begin{array}{l}\text { Type of the } \\
\text { sensory } \\
\text { system }\end{array}$ & $\begin{array}{c}\text { No of healthy } \\
\text { volunteers / } \\
\text { No of } \\
\text { amputees } \\
\text { volunteers }\end{array}$ & $\begin{array}{l}\text { The details of the } \\
\text { using stimulator }\end{array}$ & $\begin{array}{l}\text { Finding and } \\
\text { conclusion }\end{array}$ \\
\hline [96] & Fingertip & $\begin{array}{l}\text { The study } \\
\text { didn't } \\
\text { include an } \\
\text { artificial } \\
\text { hand }\end{array}$ & $\begin{array}{c}\text { LSMN- } \\
\text { TR2252 } \\
\text { thermistor } \\
\text { (Accuthermo } \\
\text { Technology, } \\
\text { Fremont,CA, } \\
\text { USA) }\end{array}$ & $10 / 0$ & $\begin{array}{l}\text { A matrix array of } \\
\text { tactile cells and a } \\
\text { Peltier element } \\
\text { attached to an air- } \\
\text { cooled heatsink }\end{array}$ & $\begin{array}{l}\text { The potential of the } \\
\text { haptic device as a } \\
\text { promising haptic } \\
\text { display for providing } \\
\text { haptic feedback in } \\
\text { teleoperation was } \\
\text { demonstrated }\end{array}$ \\
\hline $\begin{array}{c}{[97,} \\
98]\end{array}$ & Upper Arm & $\begin{array}{c}\text { myoelectric } \\
\text { prosthetic } \\
\text { hand }\end{array}$ & $\begin{array}{l}\text { K type "AD- } \\
1214 \text { " } \\
\text { thermocouple }\end{array}$ & $10 / 0$ & Peltier element & $\begin{array}{c}\text { The temperature } \\
\text { distinction evaluation } \\
\text { tests for ten } \\
\text { participants present } \\
\text { average success rate of } \\
88 \% \text {. }\end{array}$ \\
\hline $\begin{array}{l}{[99} \\
100]\end{array}$ & $\begin{array}{l}\text { Not clear } \\
\text { in the } \\
\text { article }\end{array}$ & $\begin{array}{l}\text { The study } \\
\text { didn't } \\
\text { include an } \\
\text { artificial } \\
\text { hand }\end{array}$ & $\begin{array}{c}\text { K type } \\
\text { Thermocouple } \\
\text { temperature } \\
\text { sensor }\end{array}$ & $0 / 0$ & $\begin{array}{c}\text { Four Peltier } \\
\text { elements of type } \\
\text { (KSMH029F, } \\
\text { KELK Ltd.) }\end{array}$ & $\begin{array}{l}\text { The recognition time } \\
\text { of variation of } \\
\text { temperature was } \\
\text { improved by } 36 \% \text { on } \\
\text { average, in comparison } \\
\text { with using one Peltier } \\
\text { element. }\end{array}$ \\
\hline [101] & Fingertip & $\begin{array}{l}\text { The study } \\
\text { didn't } \\
\text { include an } \\
\text { artificial } \\
\text { hand }\end{array}$ & $\begin{array}{c}\text { FTX700D } \\
\text { H-bridge from } \\
\text { AccuThermo }\end{array}$ & $0 / 0$ & $\begin{array}{l}\text { A novel Thermo- } \\
\text { tactile } \\
\text { Multimodal } \\
\text { Display }\end{array}$ & $\begin{array}{l}\text { The design concept of } \\
\text { the haptic device with } \\
\text { very high-temperature } \\
\text { variations response } \\
\text { allows it to simulate } \\
\text { the contact with many }\end{array}$ \\
\hline
\end{tabular}




\begin{tabular}{|c|c|c|c|c|c|c|}
\hline & & & & & $\begin{array}{c}\text { bodies found in our } \\
\text { daily environment. }\end{array}$ \\
\hline$[102]$ & Fingertip & $\begin{array}{c}\text { The study } \\
\text { didn't } \\
\text { include an } \\
\text { artificial } \\
\text { hand }\end{array}$ & $\begin{array}{c}\text { Virtual tactile } \\
\text { sensory } \\
\text { system }\end{array}$ & $3 / 0$ & $\begin{array}{c}\text { Peltier cells (two } \\
\text { Telecom-Grade } \\
\text { cooler model } \\
\text { 20038/035/025M } \\
\text { Ferrotec, Santa } \\
\text { Clara, CA) }\end{array}$ & $\begin{array}{c}\text { The ability of the } \\
\text { Haptic Thimble to } \\
\text { provide consistent and } \\
\text { informative } \\
\text { characterization about } \\
\text { the virtual temperature } \\
\text { was improved } \\
\text { experimentally }\end{array}$ \\
\hline
\end{tabular}

\section{Non-Invasive Hybrid Feedback Stimulation Techniques}

Several previous studies investigated how to use the simultaneous application of two or more different types of haptic feedback to influence the human sensory perception, where such system is called the hybrid feedback stimulation system. From those studies, the hybrid system has shown better performance than of each separate feedback type [103]. For example, combining the squeeze and the skin stretch feedback displays convey the feeling of the contact pressure during grasping objects smoothly to the patient's brain [104]. A short outline of the works on hybrid feedback stimulation display is presented in Table 7.

In [105], authors investigated the ability of the amputees to discriminate multi-site tactile stimuli in sensory refinement tasks. Two main challenges were faced in this study. The first one is to provide the pressure sensing that occurs on the prosthetic fingertips directly to the subjects' brain as a pressure stimulation on their residual forearm; it is called multi-site mechano-tactile (MT) display. The second challenge is to use the vibration feedback display to convey the contact pressure feeling to the amputees; it is called a multi-site vibrotactile (VT) display. Results showed that there is no significant difference in the display of the MT feedback and VT feedback, but with a simple superior in preference of MT system over the VT system. This is due to the fact that the volunteers, who have a good response due to the MT system, are also showing high stimulation level when excited with the VT system. The prosthetic hand extended with force sensors on each fingertip was displayed in Fig. 10. a, while the VT and MT actuators were presented in Fig. 10. b and 10. c, respectively. A similar comparison study between the vibration and skin stretch feedback stimulations has been presented in [106] to investigate which of them gives better performance in providing the virtual proprioception task. The benchtop skin stretch device and C2 vibrational tactor were used as a skin stretch display and vibration display, respectively. The evaluation tests with ten healthy participants showed that the skin stretch gave superior results than the vibration display, especially at the low-inertia configuration and at low velocity.

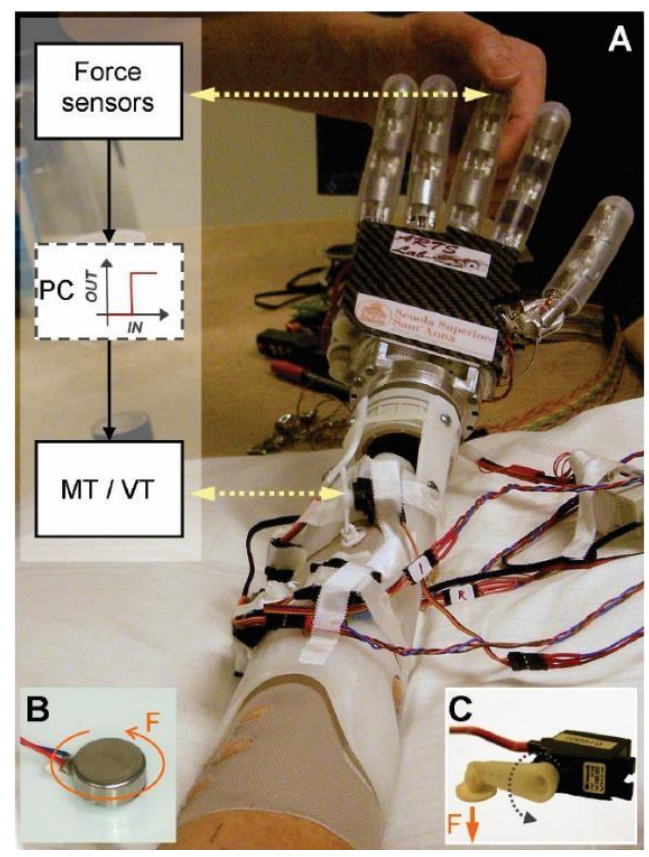

Fig. 10 - The integrting of MT and VT displays to the prosthetic hand [105]. 
On the other hand, a novel small size, lightweight, low power consumption preliminary prototype of a hybrid feedback device has been designed in [107]. The new multi-modal haptic device consists of the pressure and vibration feedback stimulators to provide useful tactile information to the users of prosthetic hand about the grasping force and the contact pressure, respectively. The validation tests showed that the hybrid haptic device has an acceptable design and prepareness for future experiment tests with the amputees volunteers. Moreover, the functionality of utilizing a multimode haptic device to increase the performance of Pisa/IIT SoftHand to the execution of safe and stable grasps was confirmed by using a hybrid feedback system with two displays [108]. The first display is a squeeze stimulator for rendering the grasping force, while the second display is a vibration stimulator for detecting the surface texture and the object's slippage.

A novel minimizing size, lightweight, and low-frequency deformation wearable haptic device with 3 DoF for rendering contact forces at the fingertip has been developed [109]. HK-282A RC servo motors were utilized to create the mechanical movement of 3-RSR asymmetric rigid parallel kinematics, as shown in Fig. 11. Depending on three evaluation tests, it can be concluded that the ability of the participants to manipulate, grasp, and lift a virtual object was increased when using the haptic device. Lastly, a BioTac sensor was integrated with the prosthetic hand to detect the contact force, surface texture, and the objects' temperature at the same time [110]. A hybrid haptic device of pressure, vibration, and thermal feedback displays was used to convey the tactile information to the users' skin. The overall results confirmed that the proposed hybrid wearable device is capable to convey the tactile information to the patients of upper limb amputation in an effective manner, where the contact pressure, temperature, thermal properties, and surface texture, which occurs on between the prosthetic hand and the objects at the same time can be discriminated.

(a)

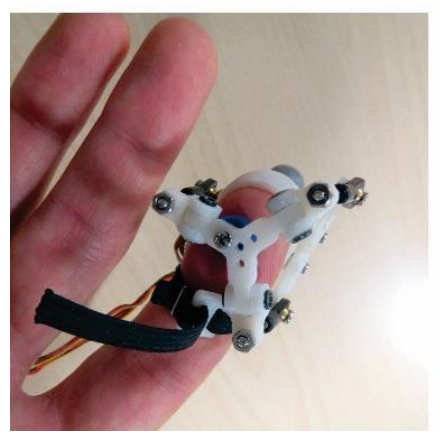

(b)

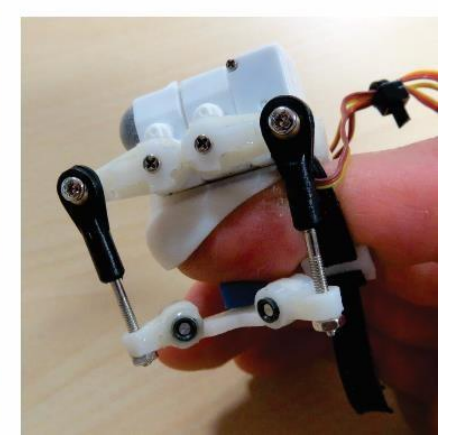

Fig. 11 - The proposed device for rendering skin stretch at the index fingertip [109]: a) Front view. b) Side view.

Table 7 - Summary of the articles that dealt with the hybrid feedback display.

\begin{tabular}{|c|c|c|c|c|c|c|}
\hline Ref. & $\begin{array}{l}\text { Location } \\
\text { of the } \\
\text { feedback } \\
\text { display }\end{array}$ & $\begin{array}{l}\text { Type of } \\
\text { the } \\
\text { artificial } \\
\text { hand }\end{array}$ & $\begin{array}{l}\text { Type of the } \\
\text { sensory } \\
\text { system }\end{array}$ & $\begin{array}{l}\text { No of healthy } \\
\text { volunteers / } \\
\text { No of } \\
\text { amputees } \\
\text { volunteers }\end{array}$ & $\begin{array}{l}\text { Type of the } \\
\text { feedback display } \\
\text { (The details of the } \\
\text { using stimulator) }\end{array}$ & $\begin{array}{l}\text { Finding and } \\
\text { conclusion }\end{array}$ \\
\hline [103] & Forearm & $\begin{array}{l}\text { The study } \\
\text { didn't } \\
\text { include an } \\
\text { artificial } \\
\text { hand }\end{array}$ & $\begin{array}{l}\text { linear Hall } \\
\text { effect sensor, } \\
\text { the SS495 } \\
\text { from } \\
\text { Honeywell } \\
\text { Ltd }\end{array}$ & $14 / 0$ & $\begin{array}{c}\text { *Pressure display } \\
\text { (a MAXON DC } \\
\text { motor (Sachseln, } \\
\text { Switzerland) and } \\
\text { piston) } \\
\text { *Vibration display } \\
\text { (Two vibrator } \\
\text { motorsof type MN: } \\
\text { 310-113) }\end{array}$ & $\begin{array}{l}\text { Integrating the } \\
\text { vibration display with } \\
\text { the pressure feedback } \\
\text { display has negative } \\
\text { effect on the normal } \\
\text { stress haptic sensation }\end{array}$ \\
\hline [104] & Forearm & $\begin{array}{c}\text { Sawyer } \\
\text { robotic arm }\end{array}$ & $\begin{array}{l}\text { two OMD- } \\
\text { 20-SE-40N 3- } \\
\text { DoF force } \\
\text { sensors } \\
\text { (Optoforce } \\
\text { Ltd, HU) }\end{array}$ & $10 / 0$ & $\begin{array}{l}\text { Squeeze and skin } \\
\text { stretch displays } \\
\text { (The hBracelet } \\
\text { consists of four } \\
\text { servo motors and } \\
\text { one linear actuator) }\end{array}$ & $\begin{array}{l}\text { The hBracelet hybrid } \\
\text { wearable device was } \\
\text { capable to convey the } \\
\text { tactile information } \\
\text { successfully and } \\
\text { improve the } \\
\text { performance of the } \\
\text { robotic hand }\end{array}$ \\
\hline
\end{tabular}




\begin{tabular}{|c|c|c|c|c|c|c|}
\hline [105] & Forearm & $\begin{array}{l}\text { Smart } \\
\text { Hand } \\
\text { research } \\
\text { prosthesis }\end{array}$ & $\begin{array}{c}\text { Pressure } \\
\text { sensor }\end{array}$ & $11 / 0$ & $\begin{array}{l}\text { *Pressure display } \\
\text { (digital servo } \\
\text { motors, Graupner } \\
\text { DS281, Germany) } \\
\text { *Vibration display } \\
\text { (ERM vibration } \\
\text { motor) }\end{array}$ & $\begin{array}{l}\text { There is no significant } \\
\text { difference in the } \\
\text { display of the MT } \\
\text { feedback and VT } \\
\text { feedback, but with a } \\
\text { simple superior in } \\
\text { preference of MT } \\
\text { system over VT } \\
\text { system }\end{array}$ \\
\hline [106] & Forearm & Virtual arm & Virtual sensor & $10 / 0$ & $\begin{array}{l}\text { *Skin stretch } \\
\text { display } \\
\text { (benchtop skin } \\
\text { stretch device) } \\
\text { *Vibration display } \\
\text { (C2 Tactor, } \\
\text { from EAI Inc) }\end{array}$ & $\begin{array}{l}\text { The evaluation tests } \\
\text { with ten healthy } \\
\text { participants showed } \\
\text { that the skin stretch } \\
\text { gave superior results } \\
\text { than the vibration } \\
\text { display, especially at } \\
\text { the low-inertia } \\
\text { configuration and at } \\
\text { low velocity }\end{array}$ \\
\hline [107] & Upper arm & $\begin{array}{l}\text { The study } \\
\text { didn't } \\
\text { include an } \\
\text { artificial } \\
\text { hand }\end{array}$ & $\begin{array}{l}\text { The study } \\
\text { didn't include } \\
\text { an sensor }\end{array}$ & $0 / 0$ & $\begin{array}{c}\text { *Pressure display } \\
\text { (Maxon Motor, } 6 \\
\text { V, } 3 \mathrm{~W} \text { ) } \\
\text { *Vibration display } \\
\text { (Two 308-100 Pico } \\
\text { Vibe vibrators) }\end{array}$ & $\begin{array}{l}\text { The hybrid haptic } \\
\text { device has an } \\
\text { acceptable design and } \\
\text { ready for the } \\
\text { experiment tests }\end{array}$ \\
\hline [108] & Upper arm & $\begin{array}{l}\text { Pisa/IIT } \\
\text { SoftHand }\end{array}$ & $\begin{array}{c}\text { Analog } \\
\text { Devices } \\
\text { ADXL327 } \\
\text { MEMS-based } \\
\text { accelerometer }\end{array}$ & $5 / 0$ & $\begin{array}{l}\text { *Squeeze display } \\
\text { ((small DC } \\
\text { Motor and band) } \\
\text { *Vibration display } \\
\text { (Small vibration } \\
\text { motor) }\end{array}$ & $\begin{array}{l}\text { The functionality of } \\
\text { utilizing a multi-mode } \\
\text { haptic device to } \\
\text { increase the } \\
\text { performance of } \\
\text { Pisa/IIT SoftHand to } \\
\text { the execution of safe } \\
\text { and stable grasps was } \\
\text { confirmed }\end{array}$ \\
\hline [109] & Fingertip & $\begin{array}{l}\text { The study } \\
\text { didn't } \\
\text { include an } \\
\text { artificial } \\
\text { hand }\end{array}$ & Virtual sensor & $19 / 0$ & $\begin{array}{l}\text { *Pressure and skin } \\
\text { stretch displays (3- } \\
\text { RSR asymmetric } \\
\text { rigid parallel } \\
\text { device with HK- } \\
\text { 282A RC servo } \\
\text { motors) }\end{array}$ & $\begin{array}{l}\text { Depending on three } \\
\text { evaluation tests, it can } \\
\text { be concluded that the } \\
\text { ability of the } \\
\text { participants to } \\
\text { manipulate, grasp, and } \\
\text { lift a virtual object } \\
\text { was increased when } \\
\text { using the haptic } \\
\text { device }\end{array}$ \\
\hline [110] & Upper arm & $\begin{array}{c}\text { Prosthetic } \\
\text { hand }\end{array}$ & $\begin{array}{c}\text { A BioTac } \\
\text { sensor }\end{array}$ & $0 / 1$ & $\begin{array}{l}\text { *Pressure display } \\
\text { (30mm Air } \\
\text { Muscle) } \\
\text { *Vibration display } \\
\text { (polyharmonic } \\
\text { tactor (C2, EAI)) } \\
\text { *Thermal display } \\
\text { (Peltier element } \\
\text { (MCPF-031-10- } \\
\text { 25)) }\end{array}$ & $\begin{array}{l}\text { The proposed hybrid } \\
\text { wearable device is } \\
\text { capable to convey the } \\
\text { tactile information in } \\
\text { an effective manner to } \\
\text { discriminate the } \\
\text { contact pressure, } \\
\text { temperature, thermal } \\
\text { properties, and } \\
\text { surface texture at the } \\
\text { same time }\end{array}$ \\
\hline [111] & Forearm & $\begin{array}{l}\text { The study } \\
\text { didn't } \\
\text { include an } \\
\text { artificial } \\
\text { hand }\end{array}$ & $\begin{array}{l}\text { The study } \\
\text { didn't include } \\
\text { any sensor }\end{array}$ & $10 / 0$ & $\begin{array}{c}\text { *Electro display } \\
\text { (two DC } \\
\text { servo motors, } \\
\text { SPEKTRUM) }\end{array}$ & $\begin{array}{l}\text { The average accuracy } \\
\text { of the subjects' } \\
\text { recognition to the } \\
\text { virtual stimulation } \\
\text { was increased from }\end{array}$ \\
\hline
\end{tabular}




\begin{tabular}{|c|c|c|c|c|c|c|}
\hline & & & & & $\begin{array}{c}\text { *Vibration display } \\
\text { (ERM vibration } \\
\text { motor) }\end{array}$ & $\begin{array}{l}29 \% \text { for vibrotactile } \\
\text { display and } 44 \% \text { for } \\
\text { electrotactile display } \\
\text { to } 72 \% \text { when two } \\
\text { stimulation systems } \\
\text { are used as a hybrid } \\
\text { system }\end{array}$ \\
\hline [112] & Forearm & $\begin{array}{l}\text { The study } \\
\text { didn't } \\
\text { include an } \\
\text { artificial } \\
\text { hand }\end{array}$ & $\begin{array}{l}\text { The study } \\
\text { didn't include } \\
\text { any sensor }\end{array}$ & $10 / 0$ & $\begin{array}{c}\text { *Electro display } \\
\text { (two DC } \\
\text { servo motors, } \\
\text { SPEKTRUM) } \\
\text { *Vibration display } \\
\text { (ERM vibration } \\
\text { motor) }\end{array}$ & $\begin{array}{l}\text { The designed multiple } \\
\text { HyVE unit of a hybrid } \\
\text { vibration and electro } \\
\text { feedback displays has } \\
\text { high operational } \\
\text { performance and } \\
\text { capacity of stock } \\
\text { multi-channel sensory } \\
\text { information at the } \\
\text { same time }\end{array}$ \\
\hline [113] & Upper arm & $\begin{array}{c}\text { Robotic } \\
\text { hand }\end{array}$ & $\begin{array}{l}\text { barometric } \\
\text { sensors } \\
\text { (MPL115A2 } \\
\text { from NXP / } \\
\text { Freescale) }\end{array}$ & $0 / 3$ & $\begin{array}{c}\text { *Pressure display } \\
\text { (two DC } \\
\text { servo motors, } \\
\text { SPEKTRUM) } \\
\text { *Vibration display } \\
\text { (ERM vibration } \\
\text { motor) }\end{array}$ & $\begin{array}{l}\text { The hybrid system } \\
\text { was found to be } \\
\text { effective in improving } \\
\text { localization and } \\
\text { intensity recognition } \\
\text { accuracy, as well as } \\
\text { decreasing the mental } \\
\text { load }\end{array}$ \\
\hline [114] & Forearm & $\begin{array}{l}\text { The study } \\
\text { didn't } \\
\text { include an } \\
\text { artificial } \\
\text { hand }\end{array}$ & $\begin{array}{l}\text { The study } \\
\text { didn't include } \\
\text { any sensor }\end{array}$ & $0 / 0$ & $\begin{array}{l}\text { *Pressure display } \\
\text { (small linear } \\
\text { servomotor) } \\
\text { *Vibration display } \\
\text { (ERM vibration } \\
\text { motor) }\end{array}$ & $\begin{array}{l}\text { The hybrid haptic } \\
\text { device has an } \\
\text { acceptable design and } \\
\text { ready for the } \\
\text { experiment tests }\end{array}$ \\
\hline [115] & Forearm & $\begin{array}{l}\text { The study } \\
\text { didn't } \\
\text { include an } \\
\text { artificial } \\
\text { hand }\end{array}$ & $\begin{array}{l}\text { Three } \\
\text { force- } \\
\text { pressure } \\
\text { sensors } \\
\text { (American } \\
\text { company } \\
\text { Interlink } \\
\text { Electronics) }\end{array}$ & $0 / 0$ & $\begin{array}{c}\text { *Pressure display } \\
\text { (servo Turnigy } \\
\text { TGY-210DMH } \\
\text { Coreless) } \\
\text { * Vibration display } \\
\text { (linear resonant } \\
\text { actuator C08-001) }\end{array}$ & $\begin{array}{l}\text { The hybrid haptic } \\
\text { device has an } \\
\text { acceptable design and } \\
\text { ready for the } \\
\text { experiment tests }\end{array}$ \\
\hline
\end{tabular}

\section{Discussion}

This study intends to present a brief literature review of previous research, focusing on how to help the patients of upper limb mutilation to restore the missing sensation through their own upper limb prostheses. The literature study involves 83 related articles sorted under the non-invasive haptic feedback stimulation system as a final set after several classification iterations. The articles are classified into six subclasses, according to the function of the haptic feedback stimulation system. The distribution of the entire 83 articles over the publication years from 2008 to 2018 is described in Fig. 12. a, where the range of publication years represents the years' limitation during the article searching process. The distribution clearly depicts that the number of articles in the field of haptic upper limb prostheses was increasing in last few years. That means, the field of this study is progressing and there is still space for future works. The distribution of articles that deals with the non-invasive hybrid feedback stimulation system is shown in Fig. 12. b. This figure shows the modernity of this research direction, as the articles work in this area are published only in the past few years. Therefore, the hybrid haptic system represents the further direction of the non-invasive feedback stimulation techniques. 
(a)

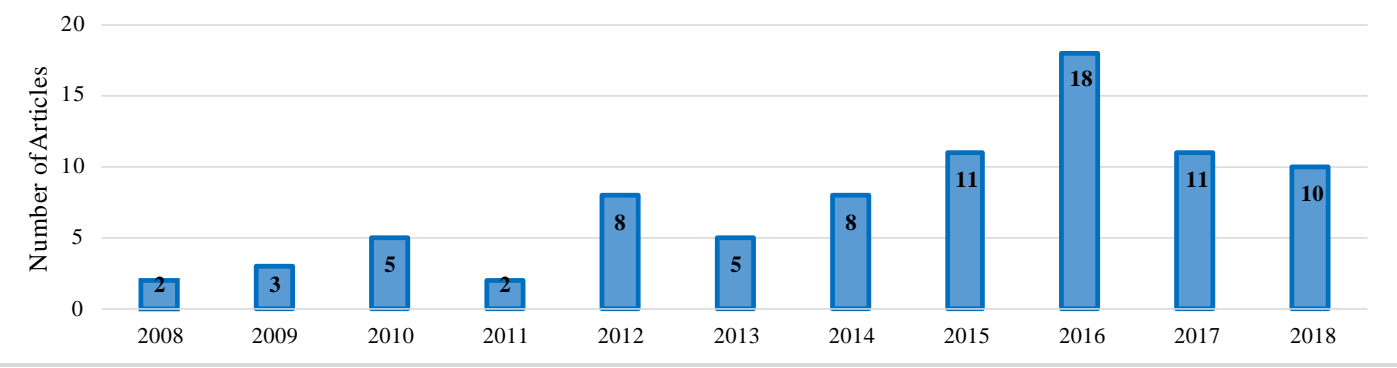

(b)

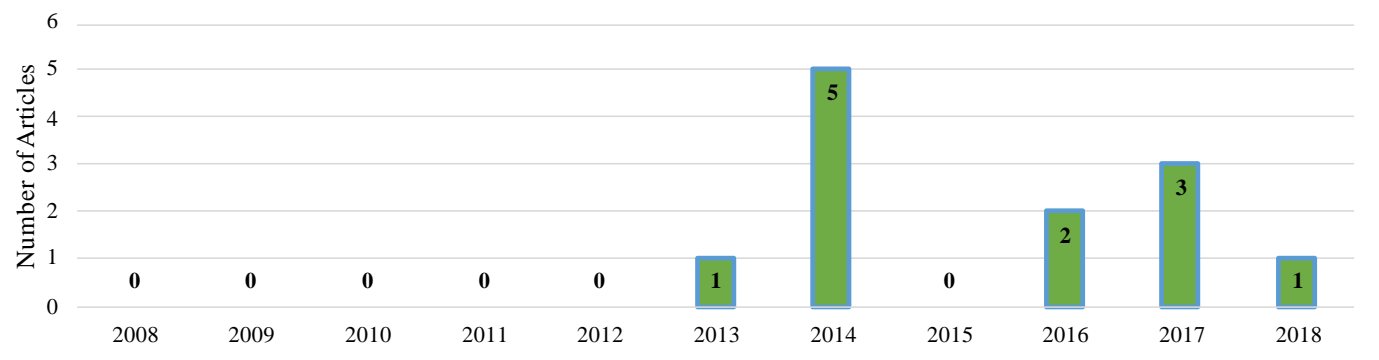

Fig. 12- Distributing the previous articles over the years of publication: a) Included all the articles that deal with the non-invasive feedback stimulation technique. b) Included the articles that deal with the hybrid feedback stimulation technique.

From all 83 previous studies, the percentage of each haptic feedback stimulation technique that been discussed in this study is presented in Fig. 13. a. Statistical analysis showed that most of the previous works are on the vibration and electro feedback stimulation displays, by mean of $28 \%$ and $20 \%$ of the total articles, respectively. This high percentage is related to the specific features of the vibration and the electro actuators. In general, they are lightweight, and with minimal cost, low noise, and low power consumption. In addition, these types of actuators are able to operate independently without auxiliary tools or supporting devices. The rest of the feedback displays been studied in the literature have similar distribution, in particular, $10 \%$ for the pressure display, $11 \%$ for the skin stretch display, $7 \%$ for squeeze display, and $8 \%$ for the thermal display. Furthermore, the hybrid feedback display was studied more, in comparison with the other techniques, with the percentage of $16 \%$. This results supports the conclusion that the noninvasive hybrid feedback stimulation system is the future direction of this field of study.

On the other hand, Fig. 13. b presents the installation positions of the haptic feedback stimulators, in order to confirm which is the best location to install the haptic wearable device on the amputees' residual parts. Most of the previous works select the forearm and the upper arm as the favorite spot to install the haptic device: $49 \%$ and $31 \%$ for the forearm and the upper arm, respectively. This is due to the original nerves of the missing hand are concentrated and passed through these positions, and thus enables the amputees to recover the feeling as real as possible. Other groups of researchers used fingertip, foot, neck and the waist to re-create the sensation and excite the amputees' brain. In general, the location of the feedback stimulator depends on several parameters, like the level of the amputation, the design of the wearable device, the final dimensions, and the net weight.

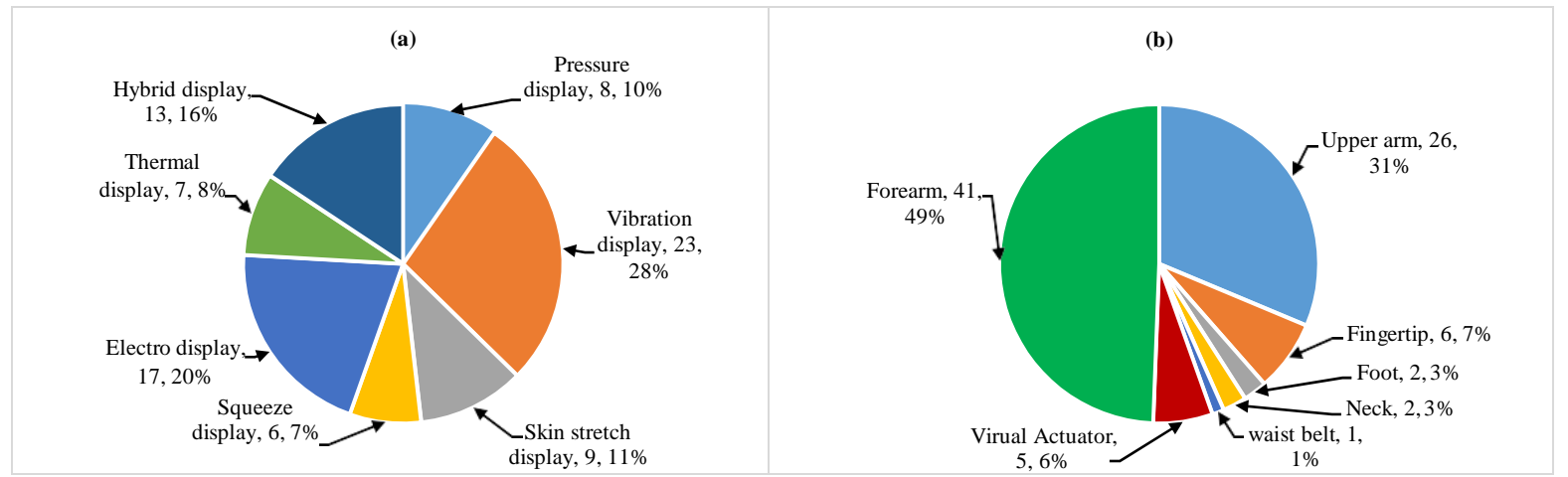

Fig. 13 - Previous articles' statistical analysis, includes: a) distributing the previous articles according to the main category. b) the installing position of the feedback stimulators. 
The statistical analysis presented in Fig. 14 answers the common question whether is it necessary to use the prosthetic hand and the amputees' subjects in the evaluation experiments. Fig. 14. a shows that $22 \%$ of the previous works used the myoelectric prosthetic hand to accomplish the experiments, while $13 \%$ of the previous studies fixed the sensors of the tactile sensory system at the jaws of the robotic arms with several degrees of freedom. Moreover, $13 \%$ of the previous articles depended on the programmed virtual hand to simulate the tasks of the real healthy hand, in order to compensate the absence of the prosthetic hand. Finally, 52\% of previous studies involved healthy volunteers with healthy biological hand to install the sensory system, for instance, using a tactile elastic glove [20] or 3D printed fingers [63] to fix the spot piezoresistive pressure sensors. Therefore, there are no artificial hands that were used in this type of studies.

Consequently, $59 \%$ of the previous works involved the healthy volunteers to implement the evaluation and the functionality tests, as shown in Fig. 14. b, while $13 \%$ of the researchers, which have utilized the prosthetic or the robotic hands in their studies, reckoned on the patients with upper limb amputation to perform the studies. Other $8 \%$ of the articles show that the healthy and the amputees are volunteered together in the same study for two main reasons. The first reason is to make a comparison study between the nervous system's response of the healthy and the amputees' volunteers. The second reason is sometimes the number of the amputees' subjects was barely enough to complete the experiments. Thus, the healthy volunteers are engaged to complete the research samples. Lastly, $11 \%$ of the previous studies focused on enhancing the performance of the feedback actuators and the effectiveness of the final design. Therefore, no volunteers were used in these types of the investigation studies.

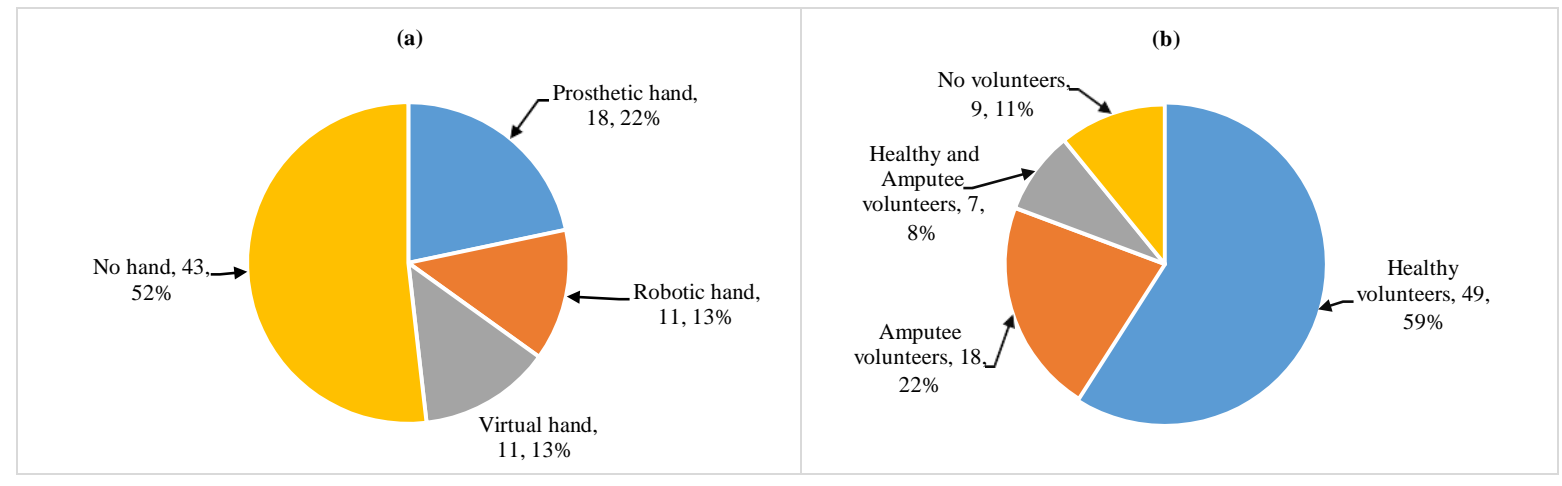

Fig. 14 - Previous experiments' statistical analysis, includes: a) type of the used artificial hand. b) type of the engaged volunteers.

\section{Conclusion}

Traumatic injury or disease can lead to the loss, or the need for amputation, of a patient's hand or arm. This loss has a major impact on the patient as different tasks of day-to-day life are complicated or made impossible. To assist patients suffering such loss, prostheses are available. Prostheses are artificial devices used to replace these missing body parts. The lack of sensation, however, is the key limitation to reestablishing the full functionality of the natural limb. It is possible to use one or more than one type of sensor or actuator at the same operation time to improve the feeling efficiency. In general, the prosthetic hand, which equipped with the haptic feedback stimulation system, has lower power consumption and longer battery life than a normal prosthetic hand. This is because it's an ability to minimize the grasping force level and control the using power. However, there are various challenges in terms of the presence of gaps, can be as a foundation for the future research works, like make an investigation about the haptic system weight and its effects on the patient comfortability. Also, to the best of our knowledge, there is no study before on the limitation of the haptic system instruments and proving if it is available to the users at any times. Finally, it is concluded that the performance of the hybrid feedback stimulation system to help the amputees to recover the sensation is more effective than using each feedback display individually.

\section{References}

[1] L. J. Marks and J. W. Michael,(2001).Science, medicine, and the future: artificial limbs. BMJ: British Medical Journal, vol. 323, p. 732,

[2] M. Yoshikawa, Y. Taguchi, S. Sakamoto, S. Yamanaka, Y. Matsumoto, T. Ogasawara, et al.,(2013).Trans-radial prosthesis with three opposed fingers. in Intelligent Robots and Systems (IROS), 2013 IEEE/RSJ International Conference on, Tokyo, Japan,, pp. 1493-1498. 
[3] D. J. Atkins, D. C. Heard, and W. H. Donovan,(1996).Epidemiologic overview of individuals with upper-limb loss and their reported research priorities. JPO: Journal of Prosthetics and Orthotics, vol. 8, pp. 2-11,

[4] V. Klinge,(1972).Effects of exteroceptive feedback and instructions on control of spontaneous galvanic skin responses. Psychophysiology, vol. 9, pp. 305-317,

[5] R. E. Prior, J. Lyman, P. A. Case, and C. M. Scott,(1976).Supplemental sensory feedback for the VA/NU myoelectric hand. Background and preliminary designs. Bull Prosthet Res, vol. 10, pp. 170-91,

[6] F. Clemente, S. Dosen, L. Lonini, M. Markovic, D. Farina, and C. Cipriani,(2017).Humans can integrate augmented reality feedback in their sensorimotor control of a robotic hand. IEEE Transactions on HumanMachine Systems, vol. 47, pp. 583-589,

[7] M. Markovic, S. Dosen, C. Cipriani, D. Popovic, and D. Farina,(2014).Stereovision and augmented reality for closed-loop control of grasping in hand prostheses. Journal of neural engineering, vol. 11, p. 046001,

[8] E. L. Graczyk, M. A. Schiefer, H. P. Saal, B. P. Delhaye, S. J. Bensmaia, and D. J. Tyler,(2016).The neural basis of perceived intensity in natural and artificial touch. Science translational medicine, vol. 8, pp. 362ra142362ra142,

[9] M. Schiefer, D. Tan, S. M. Sidek, and D. J. Tyler,(2015).Sensory feedback by peripheral nerve stimulation improves task performance in individuals with upper limb loss using a myoelectric prosthesis. Journal of neural engineering, vol. 13, p. 016001,

[10] C. Antfolk, C. Balkenius, G. Lundborg, B. Rosén, and F. Sebelius,(2010).Design and technical construction of a tactile display for sensory feedback in a hand prosthesis system. Biomedical engineering online, vol. 9, p. 50,

[11] P. Slade, A. Akhtar, M. Nguyen, and T. Bretl,(2015).Tact: Design and performance of an open-source, affordable, myoelectric prosthetic hand. in Robotics and Automation (ICRA), 2015 IEEE International Conference on, pp. 6451-6456.

[12] M. T. Hussein and M. N. Nemah,(2015).Control of a two-link (rigid-flexible) manipulator. in 2015 3rd RSI International Conference on Robotics and Mechatronics (ICROM), pp. 720-724.

[13] M. N. Nemah,(2015).CONTROL OF FLEXIBLE ROBOT USING VISION SENSOR MEASUREMENTS. AlQadisiya Journal for Engineering Sciences, vol. 8, pp. 284-297,

[14] M. N. Nemah,(2018).Modelling and Development of Linear and Nonlinear Intelligent Controllers for Anti-lock Braking Systems (ABS). Journal of University of Babylon, vol. 26, pp. 1-12,

[15] J. Annisa, A. Z. Abidin, I. M. Darus, and M. Tokhi,(2018).Controlling the non-parametric modeling of Double Link Flexible Robotic Manipulator using Hybrid PID tuned by P-Type ILA. International Journal of Integrated Engineering, vol. 10,

[16] H. A. Rahman, K. N. Samuthram, C. F. Yeong, and K. X. Khor,(2018).A Simple Position Sensing Device for Upper Limb Rehabilitation. International Journal of Integrated Engineering, vol. 10,

[17] M. T. Hussein and M. N. Nemah,(2015).Modeling and control of quadrotor systems. in 2015 3rd RSI International Conference on Robotics and Mechatronics (ICROM), pp. 725-730.

[18] Y. Zheng, Y. Peng, G. Wang, X. Liu, X. Dong, and J. Wang,(2016).Development and evaluation of a sensor glove for hand function assessment and preliminary attempts at assessing hand coordination. Measurement, vol. 93, pp. 1-12,

[19] B. Matulevich, G. E. Loeb, and J. A. Fishel,(2013).Utility of contact detection reflexes in prosthetic hand control. in Intelligent Robots and Systems (IROS), 2013 IEEE/RSJ International Conference on, pp. 4741-4746.

[20] M. N. Nemah, C. Y. Low, P. Ong, and N. A. C. Zakaria,(2018).Development and evaluation of a spot sensor glove for the tactile prosthetic hand. International Journal of Engineering and Technology (UAE), vol. 7, pp. 63-69,

[21] L. Osborn, N. V. Thakor, and R. Kaliki,(2013).Utilizing tactile feedback for biomimetic grasping control in upper limb prostheses. in SENSORS, 2013 IEEE, pp. 1-4.

[22] L. Osborn, W. W. Lee, R. Kaliki, and N. Thakor,(2014).Tactile feedback in upper limb prosthetic devices using flexible textile force sensors. in Biomedical Robotics and Biomechatronics (2014 5th IEEE RAS \& EMBS International Conference on, , Sao Paulo, Brazil, pp. 114-119.

[23] S. Youn, D. G. Seo, and Y.-H. Cho,(2013).A micro tactile transceiver for fingertip motion recognition and texture generation. Sensors and Actuators A: Physical, vol. 195, pp. 105-112,

[24] J. A. Fishel, V. J. Santos, and G. E. Loeb,(2008).A robust micro-vibration sensor for biomimetic fingertips. in Biomedical Robotics and Biomechatronics, 2008. BioRob 2008. 2nd IEEE RAS \& EMBS International Conference on, pp. 659-663.

[25] E. Kerr, T. McGinnity, and S. Coleman,(2018).Material recognition using tactile sensing. Expert Systems with Applications, vol. 94, pp. 94-111,

[26] M. Aziziaghdam and E. Samur,(2017).Real-Time Contact Sensory Feedback for Upper Limb Robotic Prostheses. IEEE/ASME Transactions on Mechatronics, vol. 22, pp. 1786-1795,

[27] G. Klute, G. Rowe, A. Mamishev, and W. Ledoux,(2007).The thermal conductivity of prosthetic sockets and liners. Prosthetics and orthotics international, vol. 31, pp. 292-299, 
[28] Y. Cho, K. Liang, F. Folowosele, B. Miller, and N. V. Thakor,(2007).Wireless temperature sensing cosmesis for prosthesis. in Rehabilitation Robotics, 2007. ICORR 2007. IEEE 10th International Conference on, pp. 672677.

[29] D. P. Cotton, P. H. Chappell, A. Cranny, N. M. White, and S. P. Beeby,(2007).A novel thick-filmpiezoelectric slip sensor for a prosthetic hand. IEEE sensors journal, vol. 7, pp. 752-761,

[30] A. Polishchuk, W. T. Navaraj, H. Heidari, and R. Dahiya,(2016).Multisensory Smart Glove for Tactile Feedback in Prosthetic Hand. Procedia Engineering, vol. 168, pp. 1605-1608,

[31] T. B. Martin, R. O. Ambrose, M. A. Diftler, R. Platt, and M. Butzer,(2004).Tactile gloves for autonomous grasping with the NASA/DARPA Robonaut. in Robotics and Automation, 2004. Proceedings. ICRA'04. 2004 IEEE International Conference on, pp. 1713-1718.

[32] M. Nabeel, K. Aqeel, M. N. Ashraf, M. I. Awan, and M. Khurram,(2016).Vibrotactile stimulation for 3D printed prosthetic hand. in Robotics and Artificial Intelligence (ICRAI), 2016 2nd International Conference on, Rawalpindi, Pakistan, pp. 202-207.

[33] L. A. Jones and N. B. Sarter,(2008).Tactile displays: Guidance for their design and application. Human factors, vol. 50, pp. 90-111,

[34] D. Pamungkas and K. Ward,(2015).Tactile sensing system using electro-tactile feedback. in Automation, Robotics and Applications (ICARA), 2015 6th International Conference on, Queenstown, New Zealand, pp. 295-299.

[35] R. S. Dahiya, G. Metta, M. Valle, and G. Sandini,(2010).Tactile sensing-from humans to humanoids. IEEE transactions on robotics, vol. 26, pp. 1-20,

[36] C. Antfolk, C. Cipriani, M. C. Carrozza, C. Balkenius, A. Björkman, G. Lundborg, et al.,(2013).Transfer of tactile input from an artificial hand to the forearm: experiments in amputees and able-bodied volunteers. Disability and Rehabilitation: Assistive Technology, vol. 8, pp. 249-254,

[37] M. O. Culjat, J. Son, R. E. Fan, C. Wottawa, J. W. Bisley, W. S. Grundfest, et al.,(2010).Remote tactile sensing glove-based system. in Engineering in Medicine and Biology Society (EMBC), 2010 Annual International Conference of the IEEE, Buenos Aires, Argentina, pp. 1550-1554.

[38] S. Fukushima, T. Nozaki, and K. Ohnishi,(2016).Development of haptic prosthetic hand for realization of intuitive operation. in Industrial Electronics Society, IECON 2016-42nd Annual Conference of the IEEE, pp. 6403-6408.

[39] S. Fukushima, H. Sekiguchi, Y. Saito, W. Iida, T. Nozaki, and K. Ohnishi,(2018).Artificial Replacement of Human Sensation Using Haptic Transplant Technology. IEEE Transactions on Industrial Electronics, vol. 65, pp. 3985-3994,

[40] K. Kim and J. E. Colgate,(2012).Haptic feedback enhances grip force control of sEMG-controlled prosthetic hands in targeted reinnervation amputees. IEEE Transactions on Neural Systems and Rehabilitation Engineering, vol. 20, pp. 798-805,

[41] G. Savioz, V. Ruchet, and Y. Perriard,(2010).Study of a miniature magnetorheological fluid actuator for haptic devices. in Advanced Intelligent Mechatronics (AIM), 2010 IEEE/ASME International Conference on, Montreal, ON, Canada, pp. 1197-1202.

[42] G. Savioz and Y. Perriard,(2012).Self-sensing of linear short-stroke actuators for multi-finger haptic interfaces using induced high frequency oscillations. in Advanced Intelligent Mechatronics (AIM), 2012 IEEE/ASME International Conference on, pp. 764-769.

[43] J. M. Fontana, R. O’Brien, E. Laciar, L. S. Maglione, and L. Molisani,(2018).Vibrotactile Stimulation in the Upper-Arm for Restoring Individual Finger Sensations in Hand Prosthesis. Journal of Medical and Biological Engineering, vol. 38, pp. 782-789,

[44] J. Bimbo, C. Pacchierotti, M. Aggravi, N. Tsagarakis, and D. Prattichizzo,(2017).Teleoperation in cluttered environments using wearable haptic feedback. in Intelligent Robots and Systems (IROS), 2017 IEEE/RSJ International Conference on, pp. 3401-3408.

[45] H. Huang, T. Li, C. Antfolk, C. Enz, J. Justiz, and V. M. Koch,(2016).Experiment and investigation of two types of vibrotactile devices. in Biomedical Robotics and Biomechatronics (BioRob), 2016 6th IEEE International Conference on, Singapore, Singapore, pp. 1266-1271.

[46] I. STOICA,(2017).Tactile Feedback Experiments for Forearm Prosthesis with Myoelectric Control. SCIENCE AND TECHNOLOGY, vol. 20, pp. 101-114,

[47] J. M. Walker, A. A. Blank, P. A. Shewokis, and M. K. O’Malley,(2015).Tactile feedback of object slip facilitates virtual object manipulation. IEEE transactions on haptics, vol. 8, pp. 454-466,

[48] M. D'Alonzo, F. Clemente, and C. Cipriani,(2015).Vibrotactile stimulation promotes embodiment of an alien hand in amputees with phantom sensations. IEEE Transactions on Neural Systems and Rehabilitation Engineering, vol. 23, pp. 450-457,

[49] T. Li, H. Huang, C. Antfolk, J. Justiz, and V. M. Koch,(2016).Tactile display on the remaining hand for unilateral hand amputees. Current Directions in Biomedical Engineering, vol. 2, pp. 399-403, 
[50] A. Cheng, K. A. Nichols, H. M. Weeks, N. Gurari, and A. M. Okamura,(2012).Conveying the configuration of a virtual human hand using vibrotactile feedback. in Haptics Symposium (HAPTICS), 2012 IEEE, pp. 155-162.

[51] M. R. Motamedi, J.-P. Roberge, and V. Duchaine,(2017).The Use of vibrotactile feedback to restore texture recognition capabilities, and the effect of subject training. IEEE Transactions on Neural Systems and Rehabilitation Engineering, vol. 25, pp. 1230-1239,

[52] H. Yamada, Y. Yamanoi, K. Wakita, and R. Kato,(2016).Investigation of a cognitive strain on hand grasping induced by sensory feedback for myoelectric hand. in Robotics and Automation (ICRA), 2016 IEEE International Conference on, Stockholm, Sweden, pp. 3549-3554.

[53] A. Ninu, S. Dosen, S. Muceli, F. Rattay, H. Dietl, and D. Farina,(2014).Closed-loop control of grasping with a myoelectric hand prosthesis: Which are the relevant feedback variables for force control? IEEE transactions on neural systems and rehabilitation engineering, vol. 22, pp. 1041-1052,

[54] F. Clemente, M. D'Alonzo, M. Controzzi, B. B. Edin, and C. Cipriani,(2016).Non-invasive, temporally discrete feedback of object contact and release improves grasp control of closed-loop myoelectric transradial prostheses. IEEE Transactions on Neural Systems and Rehabilitation Engineering, vol. 24, pp. 1314-1322,

[55] E. Raveh, J. Friedman, and S. Portnoy,(2018).Visuomotor behaviors and performance in a dual-task paradigm with and without vibrotactile feedback when using a myoelectric controlled hand. Assistive Technology, vol. 30, pp. 274-280,

[56] M. D'Alonzo, C. Cipriani, and M. C. Carrozza,(2011).Vibrotactile sensory substitution in multi-fingered hand prostheses: Evaluation studies. in Rehabilitation Robotics (ICORR), 2011 IEEE International Conference on, pp. 1-6.

[57] C. Cipriani, M. D’Alonzo, and M. C. Carrozza,(2012).A miniature vibrotactile sensory substitution device for multifingered hand prosthetics. IEEE transactions on biomedical engineering, vol. 59, pp. 400-408,

[58] P. Kapur, S. Premakumar, S. A. Jax, L. J. Buxbaum, A. M. Dawson, and K. J. Kuchenbecker,(2009).Vibrotactile feedback system for intuitive upper-limb rehabilitation. in EuroHaptics conference, 2009 and Symposium on Haptic Interfaces for Virtual Environment and Teleoperator Systems. World Haptics 2009. Third Joint, pp. 621622.

[59] K. Bark, P. Khanna, R. Irwin, P. Kapur, S. A. Jax, L. J. Buxbaum, et al.,(2011).Lessons in using vibrotactile feedback to guide fast arm motions. in World Haptics Conference (WHC), 2011 IEEE, pp. 355-360.

[60] R. Christiansen, J. L. Contreras-Vidal, R. B. Gillespie, P. A. Shewokis, and M. K. O'Malley,(2013).Vibrotactile feedback of pose error enhances myoelectric control of a prosthetic hand. in World Haptics Conference (WHC), 2013, pp. 531-536.

[61] N. M. Hanif, P. Chappell, A. Cranny, and N. White,(2013).Vibratory feedback for artificial hands. in Electronics, Computer and Computation (ICECCO), 2013 International Conference on, pp. 247-250.

[62] N. Gurari, K. Smith, M. Madhav, and A. M. Okamura,(2009).Environment discrimination with vibration feedback to the foot, arm, and fingertip. in Rehabilitation Robotics, 2009. ICORR 2009. IEEE International Conference on, pp. 343-348.

[63] L. C. Y. Mohammed N. N., Ong P., et al,(2018).A vibrotactile prosthetic device for detection of contact pressure and surface texture in upper extremity. In progress: International Journal of Advanced Robotic Systems,

[64] M. Aboseria, F. Clemente, L. F. Engels, and C. Cipriani,(2018).Discrete Vibro-Tactile Feedback Prevents Object Slippage in Hand Prostheses More Intuitively Than Other Modalities. IEEE Transactions on Neural Systems and Rehabilitation Engineering, vol. 26, pp. 1577-1584,

[65] O. Kayhan, A. K. Nennioglu, and E. Samur,(2018).A skin stretch tactor for sensory substitution of wrist proprioception. in Haptics Symposium (HAPTICS), 2018 IEEE, San Francisco, CA, USA, pp. 26-31.

[66] E. Battaglia, J. P. Clark, M. Bianchi, M. G. Catalano, A. Bicchi, and M. K. O'Malley,(2017).The Rice Haptic Rocker: skin stretch haptic feedback with the Pisa/IIT SoftHand. in World Haptics Conference (WHC), 2017 IEEE, Munich, Germany, pp. 7-12.

[67] M. Rossi, M. Bianchi, E. Battaglia, M. G. Catalano, and A. Bicchi,(2018).Hap-pro: a wearable haptic device for proprioceptive feedback. IEEE Transactions on Biomedical Engineering,

[68] K. Bark, J. Wheeler, G. Lee, J. Savall, and M. Cutkosky,(2009).A wearable skin stretch device for haptic feedback. in EuroHaptics conference, 2009 and Symposium on Haptic Interfaces for Virtual Environment and Teleoperator Systems. World Haptics 2009. Third Joint, Salt Lake City, UT, USA, pp. 464-469.

[69] K. Bark, J. Wheeler, P. Shull, J. Savall, and M. Cutkosky,(2010).Rotational skin stretch feedback: A wearable haptic display for motion. IEEE Transactions on Haptics, vol. 3, pp. 166-176,

[70] J. Wheeler, K. Bark, J. Savall, and M. Cutkosky,(2010).Investigation of rotational skin stretch for proprioceptive feedback with application to myoelectric systems. IEEE Transactions on Neural Systems and Rehabilitation Engineering, vol. 18, pp. 58-66,

[71] F. Chinello, C. Pacchierotti, N. G. Tsagarakis, and D. Prattichizzo,(2016).Design of a wearable skin stretch cutaneous device for the upper limb. in Haptics Symposium (HAPTICS), 2016 IEEE, pp. 14-20.

[72] F. Chinello, C. Pacchierotti, J. Bimbo, N. G. Tsagarakis, and D. Prattichizzo,(2018).Design and evaluation of a wearable skin stretch device for haptic guidance. IEEE Robotics and Automation Letters, vol. 3, pp. 524-531, 
[73] J. P. Clark, S. Y. Kim, and M. K. O'Malley,(2018).The rice haptic rocker: Altering the perception of skin stretch through mapping and geometric design. in IEEE Haptics Symposium (HAPTICS), San Francisco, CA, USA.

[74] S. Casini, M. Morvidoni, M. Bianchi, M. Catalano, G. Grioli, and A. Bicchi,(2015).Design and realization of the cuff-clenching upper-limb force feedback wearable device for distributed mechano-tactile stimulation of normal and tangential skin forces. in Intelligent Robots and Systems (IROS), 2015 IEEE/RSJ International Conference on, , Hamburg, Germany, pp. 1186-1193.

[75] S. B. Godfrey, M. Bianchi, A. Bicchi, and M. Santello,(2016).Influence of force feedback on grasp force modulation in prosthetic applications: A preliminary study. in Engineering in Medicine and Biology Society (EMBC), 2016 IEEE 38th Annual International Conference of the, pp. 5439-5442.

[76] E. Treadway, B. Gillespie, D. Bolger, A. Blank, M. O'Malley, and A. Davis,(2015).The role of auxiliary and referred haptic feedback in myoelectric control. in World Haptics Conference (WHC), 2015 IEEE, Evanston, IL, USA, pp. 13-18.

[77] T. Morita, T. Kikuchi, and C. Ishii,(2016).Development of Sensory Feedback Device for Myoelectric Prosthetic Hand to Provide Hardness of Objects to Users. Journal of Robotics and Mechatronics, vol. 28, pp. 361-370,

[78] M. Bianchi, G. Valenza, A. Serio, A. Lanata, A. Greco, M. Nardelli, et al.,(2014).Design and preliminary affective characterization of a novel fabric-based tactile display. in Haptics Symposium (HAPTICS), 2014 IEEE, , Houston, TX, USA, pp. 591-596.

[79] D. D. Damian, M. Ludersdorfer, Y. Kim, A. H. Arieta, R. Pfeifer, and A. M. Okamura,(2012).Wearable haptic device for cutaneous force and slip speed display. in Robotics and Automation (ICRA), 2012 IEEE International Conference on, Saint Paul, MN, USA, pp. 1038-1043.

[80] M. Franceschi, L. Seminara, S. Dosen, M. Strbac, M. Valle, and D. Farina,(2017).A system for electrotactile feedback using electronic skin and flexible matrix electrodes: Experimental evaluation. IEEE transactions on haptics, vol. 10, pp. 162-172,

[81] M. Štrbac, M. Isaković, M. Belić, I. Popović, I. Simanic, D. Farina, et al.,(2017).Short-and long-term learning of feedforward control of a myoelectric prosthesis with sensory feedback by amputees. IEEE Trans. Neural Syst. Rehabil. Eng.[Internet], vol. 25, pp. 2133 - 2145,

[82] M. Štrbac, M. Belić, M. Isaković, V. Kojić, G. Bijelić, I. Popović, et al.,(2016).Integrated and flexible multichannel interface for electrotactile stimulation. Journal of neural engineering, vol. 13, p. 046014,

[83] S. Dosen, M. Markovic, M. Strbac, V. Kojić, G. Bijelić, T. Keller, et al.,(2017).Multichannel electrotactile feedback with spatial and mixed coding for closed-loop control of grasping force in hand prostheses. IEEE Transactions on Neural Systems and Rehabilitation Engineering, vol. 25, pp. 183-195,

[84] M. Franceschi, L. Seminara, L. Pinna, S. Dosen, D. Farina, and M. Valle,(2015).Preliminary evaluation of the tactile feedback system based on artificial skin and electrotactile stimulation. in 2015 37th Annual International Conference of the IEEE Engineering in Medicine and Biology Society (EMBC), , Milan, Italy, pp. 4554-4557.

[85] G. Chai, S. Li, X. Sui, Z. Mei, L. He, C. Zhong, et al.,(2013).Phantom finger perception evoked with transcutaneous electrical stimulation for sensory feedback of prosthetic hand. in Neural Engineering (NER), 2013 6th International IEEE/EMBS Conference on, pp. 271-274.

[86] X. Liu, G. Chai, H. Qu, and N. Lan,(2015).A sensory feedback system for prosthetic hand based on evoked tactile sensation. in Engineering in Medicine and Biology Society (EMBC), 2015 37th Annual International Conference of the IEEE, pp. 2493-2496.

[87] E. I. Germany, E. J. Pino, and P. E. Aqueveque,(2016).Myoelectric intuitive control and transcutaneous electrical stimulation of the forearm for vibrotactile sensation feedback applied to a 3D printed prosthetic hand. in Engineering in Medicine and Biology Society (EMBC), 2016 IEEE 38th Annual International Conference of the, Orlando, FL, USA, pp. 5046-5050.

[88] L. Jiang, Q. Huang, D. Yang, S. Fan, and H. Liu,(2018).A novel hybrid closed-loop control approach for dexterous prosthetic hand based on myoelectric control and electrical stimulation. Industrial Robot: An International Journal,

[89] S. Dosen, M.-C. Schaeffer, and D. Farina,(2014).Time-division multiplexing for myoelectric closed-loop control using electrotactile feedback. Journal of neuroengineering and rehabilitation, vol. 11, p. 138,

[90] M. A. Schweisfurth, M. Markovic, S. Dosen, F. Teich, B. Graimann, and D. Farina,(2016).Electrotactile EMG feedback improves the control of prosthesis grasping force. Journal of neural engineering, vol. 13, p. 056010,

[91] L. Jiang, Q. Huang, J. Zhao, D. Yang, S. Fan, and H. Liu,(2014).Noise cancellation for electrotactile sensory feedback of myoelectric forearm prostheses. in Information and Automation (ICIA), 2014 IEEE International Conference on, pp. 1066-1071.

[92] H. Xu, D. Zhang, J. C. Huegel, W. Xu, and X. Zhu,(2016).Effects of different tactile feedback on myoelectric closed-loop control for grasping based on electrotactile stimulation. IEEE Transactions on Neural Systems and Rehabilitation Engineering, vol. 24, pp. 827-836,

[93] M. Isaković, M. Belić, M. Štrbac, I. Popović, S. Došen, D. Farina, et al.,(2016).Electrotactile feedback improves performance and facilitates learning in the routine grasping task. European journal of translational myology, vol. 26, 
[94] P. Li, G. Chai, K. Zhu, N. Lan, and X. Sui,(2015).Effects of electrode size and spacing on sensory modalities in the phantom thumb perception area for the forearm amputees. in EMBC, pp. 3383-3386.

[95] G. Chai, D. Zhang, and X. Zhu,(2017).Developing non-somatotopic phantom finger sensation to comparable levels of somatotopic sensation through user training with electrotactile stimulation. IEEE Transactions on Neural Systems and Rehabilitation Engineering, vol. 25, pp. 469-480,

[96] S. Gallo, C. Son, H. J. Lee, H. Bleuler, and I.-J. Cho,(2015).A flexible multimodal tactile display for delivering shape and material information. Sensors and Actuators A: Physical, vol. 236, pp. 180-189,

[97] Y. Ueda and C. Ishii,(2016).Development of a feedback device of temperature sensation for a myoelectric prosthetic hand by using Peltier element. in 2016 International Conference on Advanced Mechatronic Systems (ICAMechS)., Melbourne, VIC, Australia, pp. 488-493.

[98] Y. Ueda and C. Ishii,(2017).Feedback device of temperature sensation for a myoelectric prosthetic hand. Advances in Science, Technology and Engineering Systems Journal, vol. 2, pp. 41- 47,

[99] K. Sato and T. Maeno,(2012).Presentation of sudden temperature change using spatially divided warm and cool stimuli. in International Conference on Human Haptic Sensing and Touch Enabled Computer Applications, pp. 457-468.

[100] M. Nakatani, K. Sato, K. Sato, Y. Kawana, D. Takai, K. Minamizawa, et al.,(2016).A novel multimodal tactile module that can provide vibro-thermal feedback. in International AsiaHaptics conference, pp. 437-443.

[101] S. Gallo, L. Cucu, N. Thevenaz, A. Sengul, and H. Bleuler,(2014).Design and control of a novel thermo-tactile multimodal display. in Haptics Symposium (HAPTICS), 2014 IEEE, pp. 75-81.

[102] M. Gabardi, D. Leonardis, M. Solazzi, and A. Frisoli,(2018).Development of a miniaturized thermal module designed for integration in a wearable haptic device. in Haptics Symposium (HAPTICS), 2018 IEEE, pp. 100105.

[103] M. R. Motamedi, M. Otis, and V. Duchaine,(2017).The Impact of Simultaneously Applying Normal Stress and Vibrotactile Stimulation for Feedback of Exteroceptive Information. Journal of Biomechanical Engineering, vol. 139, pp. 061004-1,

[104] L. Meli, I. Hussain, M. Aurilio, M. Malvezzi, M. O'Malley, and D. Prattichizzo,(2018).The hBracelet: a wearable haptic device for the distributed mechanotactile stimulation of the upper limb. IEEE Robotics and Automation Letters, vol. 3, pp. 2198 - 2205,

[105] C. Antfolk, M. D'Alonzo, M. Controzzi, G. Lundborg, B. Rosén, F. Sebelius, et al.,(2013).Artificial redirection of sensation from prosthetic fingers to the phantom hand map on transradial amputees: vibrotactile versus mechanotactile sensory feedback. IEEE transactions on neural systems and rehabilitation engineering, vol. 21, pp. 112-120,

[106] K. Bark, J. W. Wheeler, S. Premakumar, and M. R. Cutkosky,(2008).Comparison of skin stretch and vibrotactile stimulation for feedback of proprioceptive information. in Symposium on Haptic Interfaces for Virtual Environments and Teleoperator Systems 2008, Reno, Nevada, USA, pp. 71-78.

[107] F. Clemente and C. Cipriani,(2014).A novel device for multi-modal sensory feedback in hand prosthetics: Design and preliminary prototype. in Haptics Symposium (HAPTICS), 2014 IEEE, pp. 569-573.

[108] A. Ajoudani, S. B. Godfrey, M. Bianchi, M. G. Catalano, G. Grioli, N. Tsagarakis, et al.,(2014).Exploring teleimpedance and tactile feedback for intuitive control of the pisa/iit softhand. IEEE transactions on haptics, vol. 7, pp. 203-215,

[109] D. Leonardis, M. Solazzi, I. Bortone, and A. Frisoli,(2017).A 3-RSR haptic wearable device for rendering fingertip contact forces. IEEE transactions on haptics, vol. 10, pp. 305-316,

[110] M. C. Jimenez and J. A. Fishel,(2014).Evaluation of force, vibration and thermal tactile feedback in prosthetic limbs. in Haptics Symposium (HAPTICS), 2014 IEEE, Houston, TX, USA, pp. 437-441.

[111] M. D'Alonzo, S. Dosen, C. Cipriani, and D. Farina,(2014).HyVE: hybrid vibro-electrotactile stimulation for sensory feedback and substitution in rehabilitation. IEEE Transactions on Neural Systems and Rehabilitation Engineering, vol. 22, pp. 290-301,

[112] M. D'Alonzo, S. Dosen, C. Cipriani, and D. Farina,(2014).HyVE — hybrid vibro-electrotactile stimulation—is an efficient approach to multi-channel sensory feedback. IEEE transactions on haptics, vol. 7, pp. 181-190,

[113] H. Huang, T. Li, C. Bruschini, C. Enz, J. Justiz, C. Antfolk, et al.,(2017).Multi-modal Sensory Feedback System for Upper Limb Amputees. in 2017 New Generation of CAS (NGCAS), Genova, Genoa, pp. 193-196.

[114] T. Li, H. Huang, J. Justiz, and V. M. Koch,(2016).A Miniature Multimodal Actuator for Effective Tactile Feedback: Design and Characterization. Procedia Engineering, vol. 168, pp. 1547-1550,

[115] E. Romero and D. Elias,(2016).Design of a non invasive haptic feedback device for transradial myoelectric upper limb prosthesis. in ANDESCON, 2016 IEEE, Arequipa, Peru, pp. 1-4. 